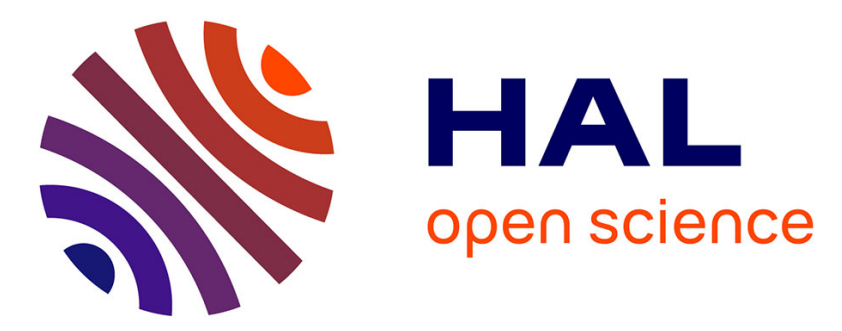

\title{
Techno-economic and Life Cycle Assessment of methane production via biogas upgrading and power to gas technology
}

Collet Pierre, Eglantine Flottes, Alain Favre, Ludovic Raynal, Hélène Pierre, Sandra Capela, Carlos Peregrina

\section{To cite this version:}

Collet Pierre, Eglantine Flottes, Alain Favre, Ludovic Raynal, Hélène Pierre, et al.. Techno-economic and Life Cycle Assessment of methane production via biogas upgrading and power to gas technology. Applied Energy, 2017, 192, pp.282-295. 10.1016/j.apenergy.2016.08.181 . hal-01519912

\section{HAL Id: hal-01519912 \\ https://hal.science/hal-01519912}

Submitted on 9 May 2017

HAL is a multi-disciplinary open access archive for the deposit and dissemination of scientific research documents, whether they are published or not. The documents may come from teaching and research institutions in France or abroad, or from public or private research centers.
L'archive ouverte pluridisciplinaire HAL, est destinée au dépôt et à la diffusion de documents scientifiques de niveau recherche, publiés ou non, émanant des établissements d'enseignement et de recherche français ou étrangers, des laboratoires publics ou privés. 
Collet Pierre ${ }^{1,2^{*}}$, Eglantine Flottes ${ }^{3,2}$, Alain Favre $^{1}$, Ludovic Raynal ${ }^{1}$, Hélène Pierre ${ }^{3}$, Sandra Capela ${ }^{3}$, Carlos Peregrina ${ }^{4}$

${ }^{1}$ IFP Energies nouvelles, 1-4 avenue de Bois-Préau, 92852 Rueil-Malmaison Cedex, France

${ }^{2}$ IDEEL, Rond-Point de l'échangeur, Les Levées, 69360 Solaize, France

${ }^{3}$ Engie, Research and Innovation Department, CRIGEN, Engie, 361 avenue du Président Wilson, 93211 Saint Denis La Plaine cedex France

${ }^{4}$ Suez-Environnement, 16 place de I'Iris, Paris la défense

*Corresponding author

Email: pierre.collet@ifpen.fr

\section{Abstract}

To decrease the use of fossil fuels and face the energetic demand, the integration of renewable energy is a necessary step. Part of this renewable energy can be supplied by the production of electricity from photovoltaic panels and windfarms. The massive use of these intermittent energies will lead to overproduction periods, and there is consequently a need to convert this surplus of electricity into a storable form of energy. Power-to-gas (PtG) technology consists in using electricity to convert water into hydrogen by electrolysis, and then to synthetize methane from carbon dioxide and hydrogen. Techno-economic and Life Cycle Assessment of methane production via the combination of anaerobic digestion and PtG technology have been applied to sewage sludge valorization. Process studies and equipment design have been addressed considering already available technologies. Sensitivity analyses have been done on biogas upgrading technologies, electricity prices, annual operation time and composition of the electricity mix with also a comparison between PtG and direct injection. It appears that the more the electricity is expensive, the longer the operation time of the methanation process must be to be competitive with injection of methane from biogas. Reduction of electricity consumption of the electrolysis step decreases production costs. Even if the current context does not feature adapted conditions to ensure an economically viable chain, the evolution of the energetic context in the next few years as well as the expected technological improvements will contribute to overall cost reduction. From an environmental point of view, continuous PtG generates more greenhouse gases than direct injection, but intermittent operation with use of renewable electricity can significantly reduce GHG emissions. From an endpoint impacts perspective, impact from continuous PtG are higher than biogas upgrading, but much lower than fossil energy. Future development of low electricity consumption of the electrolysis process, and integration of renewable credits from $\mathrm{CO}_{2}$ valorization can increase the competitiveness of this technology. 
Keywords: Life Cycle Assessment (LCA); Power-to-Gas; Methane; $\mathrm{CO}_{2}$ valorization; Energy storage; Production costs

\section{Introduction}

Even if fossils fuels accounted for 83\% of total primary energy supply in 2008 (IPCC 2011), the use of fossil energy faces many issues: decreasing reserves, emissions of greenhouses gas (GHG) and other pollutants during their combustion, but also dependence to importations, with the associated risks. It is consequently compulsory to develop alternative energy production technologies. Renewable energy can play a central role in minimizing these issues, and can be partly supplied by electricity from renewable sources, like photovoltaic panels and windfarms. This electricity emits less GHG (Varun et al. 2009) and pollutants (Turconi et al. 2013; Turconi et al. 2014) than fossil fuels (except nuclear electricity), and can be produced almost all over the planet (de Vries et al. 2007). Nevertheless, renewable electricity production faces two major drawbacks: first its intermittency, with a production which cannot be adjusted to electricity demand, and second its substitution to high energy density fuels, especially in transport and heat (Sterner 2009).

While renewable electricity represents a small proportion of electricity production in Europe (24.7\%) and in France (16.5\%) in 2014 (http://ec.europa.eu/eurostat/statisticsexplained/index.php/Electricity_production_and_supply_statistics), recent publication of the European Commission on energy production forecasts a large share of renewables (between $64 \%$ and 97\% depending on the scenarios) in the electricity mix in 2050 (European Parliament 2011), and scenarios developed by the ADEME (ADEME 2015) go as far as to propose fully renewable electricity mix.

To fulfill the needs of electricity demand with the integration of more renewables in the electricity mix, the installed capacity should be increased. This massive electricity production from renewable energies will lead to overproduction periods, where produced electricity would not be totally employed. Therefore there is a need to store this energy. Several electricity storage technologies are available like batteries, pumped hydropower plants, compressed air energy storage or hydrogen storage technologies, with different prices, run times and storage capacities (Hadjipaschalis et al. 2009). Pumped hydropower technology is the most massive storage technology available today, and is generally enough to balance the current electrical system. However it will be probably inadequate to store large amounts of overproduced electricity (ADEME 2014) and it has already been largely deployed. In this perspective, natural gas network offers a high storage capacity (for example 135 TWh in France, (DGEC (Direction générale de l'énergie et du climat) 2011)), and therefore conversion of electricity into gas would offer an interesting leverage to valorize overproduced electricity. In this perspective, production of methane $\left(\mathrm{CH}_{4}\right)$ by power-to-gas $(\mathrm{PtG})$ technology can greatly increase the 
total production of $\mathrm{CH}_{4}$ from biogas by combining carbon dioxide $\left(\mathrm{CO}_{2}\right)$ contained in the biogas and converted to $\mathrm{CH}_{4}$ via methanation with $\mathrm{CH}_{4}$ already present in the biogas (Mohseni et al. 2012; Reiter \& Lindorfer 2015; Zoss et al., 2016). PtG is defined here as using electricity to convert water into hydrogen $\left(\mathrm{H}_{2}\right)$ by electrolysis, and then to synthetize methane from carbon dioxide $\left(\mathrm{CO}_{2}\right)$ and $\mathrm{H}_{2}$ through methanation (Sabatier reaction). H2 production from electrolysis plays a key role in integrated energy system (Yan, 2016), as fuel for transportation for instance (Nistor et al., 2016). Furthermore, the synthesis of methane through methanation can strongly contribute to large scale energy storage, as $\mathrm{CH}_{4}$ injection is not limited in the gas grid, contrary to hydrogen which also faces process and safety management issues.

Both economic and environmental criteria are crucial to fully assess the relevance of a new technology. In this study we propose a model for $\mathrm{CH}_{4}$ production from $\mathrm{PtG}$ that evaluates these two dimensions of sustainability, by taking into account intermittent operation functioning. Economic assessment is done by calculating capital expenditures (CAPEX) and operational expenditures (OPEX) for each analyzed configuration, as in de Boer et al., (2014). Economic assessment of methane production from PtG have been proposed recently (Götz et al., 2016), with sometimes the use of time dependent optimization approach (Rivarolo et al., 2014). Environmental evaluation is done with Life Cycle Assessment (LCA), a standardized tool allowing to assess the environmental impacts of the whole cycle of a process, from raw extraction to final wastes management (ISO 2006). It should be noticed that it is an attributional study (and not consequential), which means that changes in the techno-economic sphere induced by large-scale production of bio $\mathrm{CH}_{4}$ from PtG are not considered (Ekvall \& Weidema 2004). In particular, this implies that the use of long-term marginal data to characterize the electric mix is not in the scope of the study (Amor et al. 2014). Several LCAs of $\mathrm{H}_{2}$ production have been done in the past years (Dufour et al. 2012; Dufour et al. 2009; Patyk et al. 2013; Cetinkaya et al. 2012), with sometimes a focus on the use of electricity from renewables (Mori et al. 2014). Nevertheless, only a few environmental studies have been conducted on $\mathrm{CH}_{4}$ production by PtG: GHG emissions of used electricity for electrolysis in Jentsch et al., (2011) or direct carbon emissions (de Boer et al. 2014), and only one Life Cycle Approach to evaluate GHG emissions (Reiter \& Lindorfer 2015). To our knowledge, this is the first time that both economic and environmental assessments are performed together to evaluate the production of bio $\mathrm{CH}_{4}$ from PtG technology with continuous and intermittent operations modes. 


\section{Methodology}

\subsection{Overview of the system}

104 PtG consists in the conversion of electricity into $\mathrm{H}_{2}$ and further into $\mathrm{CH}_{4}$, which can be stored without 105 restriction in the natural gas network. $\mathrm{CH}_{4}$ can then be further used for different purpose: storage of 106 electricity, heat production, raw materials for chemical industry and transportation services via NGV 107 production. In this paper, we will focus on the production of heat from $\mathrm{CH}_{4}$, as it is the main use of 108 natural gas, from two different sources: from biogas upgrading, with no valorization of the $\mathrm{CO}_{2}$, or 109 from biogas upgrading and $\mathrm{CO}_{2}$ conversion into $\mathrm{CH}_{4}$ via methanation (Figure 1). Different configurations are analyzed : $\mathrm{CH} 4$ from methanation after biogas upgrading, $\mathrm{CH} 4$ from methanation of the biogas without upgrading (direct methanation), and finally $\mathrm{CH} 4$ from biogas upgrading without methanation. A fossil reference system (natural gas) is also included in the LCA. The system assessed in the model includes all steps from biogas production to $\mathrm{CH}_{4}$ combustion in a boiler: anaerobic digestion of sewage sludge, biogas upgrading and compression, electrolysis, methanation, completion, injection in the gas network, and combustion. The wastewater treatment plant of the study is designed for a population equivalent of 300000 inhabitants. The daily quantity of sewage sludge processed is $16440 \mathrm{~kg}$ of dry matter, which leads to a biogas production of $230 \mathrm{~m}^{3} \cdot \mathrm{h}^{-1}$. The anaerobic digestion plant, as well as the electrolysis and the methanation installations are supposed to be near the wastewater treatment plant. The inventory is based on figures derived from academic resources, internal communications with industrials and processes described in the Ecoinvent database (Frischknecht et al. 2007). The location of the system is in France; as a consequence the electric mix is the French one, with a low carbon content. Infrastructures are included in the economic assessment but are not considered in the LCA, in line with the assessment of renewable energy production in The Renewable Energy Directive (Parliament 2009). 
a)

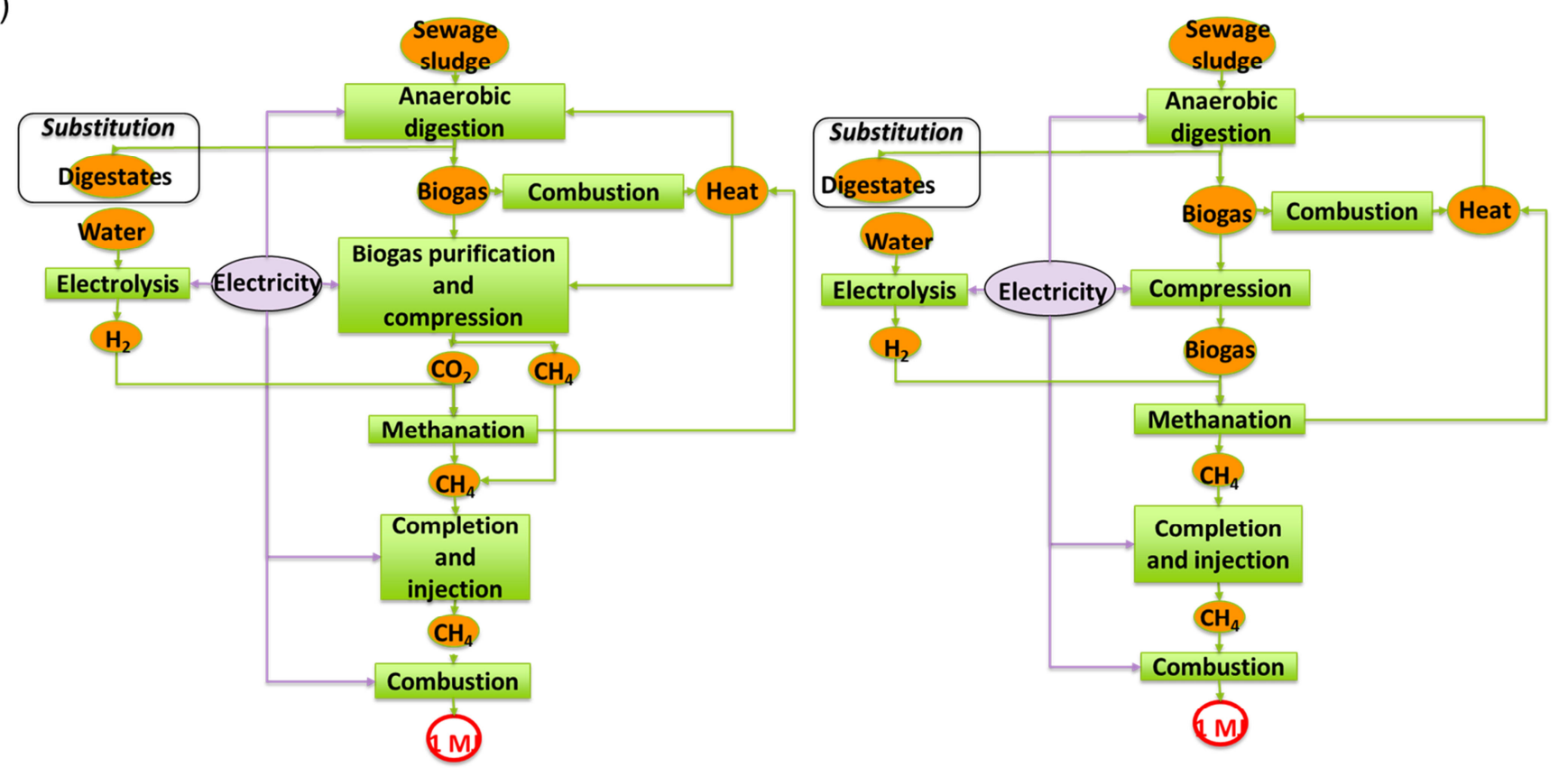

b)

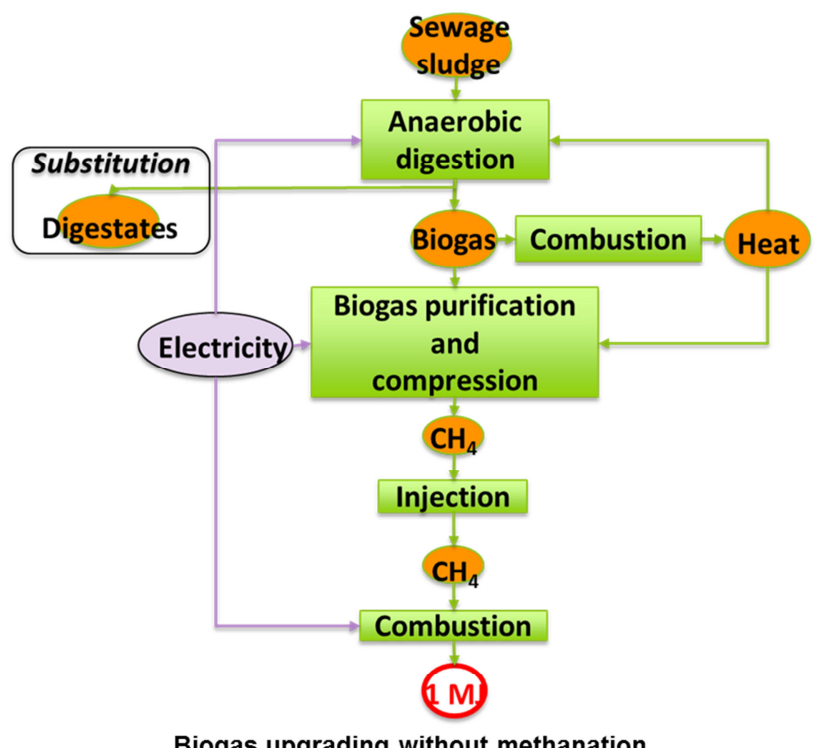

Figure 1: Overview of biomethane production with (a) and without (b) $\mathrm{CH}_{4}$ synthesis via methanation

\subsection{Anaerobic digestion step}

128 The data used for the functioning of the anaerobic digestion plant are summed up in Table 1. The 129 heat necessary for operating the anaerobic digestion plant is provided by burning part of the 130 produced biogas in a boiler and by the recovery of wasted heat from methanation when it is 131 functioning. Compositions of the biogas and the digestates come from literature survey and from 132 Suez Environment internal data. Biogenic $\mathrm{CH}_{4}$ emissions occur during biogas production and 133 digestates storage, and $\mathrm{NH}_{3}$ and $\mathrm{N}_{2} \mathrm{O}$ emissions are linked with the spreading of the digestates on the 

carbon of the digestates is entirely reemitted in the environment.

Table 1: Main assumptions at the anaerobic digestion step

\begin{tabular}{|c|c|c|}
\hline Description & Values & Reference \\
\hline \multicolumn{3}{|l|}{ Inputs } \\
\hline Sewage sludge & $685 \mathrm{~kg} \cdot \mathrm{h}^{-1}$ & \\
\hline Electricity consumption & $336{\mathrm{MJ} . \mathrm{h}^{-1}}^{-1}$ & (Frank et al. 2012) \\
\hline Heat consumption & $1343{\mathrm{MJ} . \mathrm{h}^{-1}}^{-1}$ & (Frank et al. 2012) \\
\hline \multicolumn{3}{|l|}{ Outputs } \\
\hline Biogas & $\begin{array}{l}230 \mathrm{~m}^{-1} \cdot \mathrm{h}^{-1} \\
0.220 \mathrm{~L} \cdot \mathrm{g}^{-1} \mathrm{SewSlu} \\
\mathrm{CH}_{4}: 65.63 \% \mathrm{~mol} / \mathrm{CO}_{2}: 34.37 \% \mathrm{~mol} \\
\mathrm{~T}: 40^{\circ} \mathrm{C} / \mathrm{P}: 1 \mathrm{bar}\end{array}$ & Present data \\
\hline Digestates & $\begin{array}{l}685 \text { kg.h } 1 \\
\text { N:55 g.kg }{ }^{-1} \text { Dig / P: } 48.5 \text { g.kg }{ }^{-1} \text { Dig / } \\
\text { K: } 4.28 \text { g.kg } \mathrm{kg}^{-1} \text { Dig }\end{array}$ & (ADEME 2011) \\
\hline Methane (biogenic) emissions & $3135 \mathrm{gCH}_{4} \cdot \mathrm{h}^{-1}$ & (Amon et al. 2006) \\
\hline $\mathrm{N}_{2} \mathrm{O}$ emissions & $808 \mathrm{gN}_{2} \mathrm{O} \cdot \mathrm{h}^{-1}$ & (Foley et al. 2010) \\
\hline $\mathrm{N}-\mathrm{NH}_{3}$ emissions & $7809 \mathrm{gN}-\mathrm{NH}_{3} \cdot \mathrm{h}^{-1}$ & (Foley et al. 2010) \\
\hline
\end{tabular}

\subsection{Biogas upgrading and compression steps}

In the present study, the impurities contained in the biogas (especially sulphur and silicone derived compounds) are removed via activated carbon adsorption, this latter step being considered as integrated with the biogas production. Biogas is thus considered as composed of $\mathrm{CH}_{4}$ and $\mathrm{CO}_{2}$ and biogas upgrading focus on $\mathrm{CO}_{2}$ removal. Four different technologies are considered for biogas upgrading, they are listed in Table 2 with their main characteristics. This table is based on different publications (Ryckebosch et al. 2011; Kaparaju 2013; IEA 2009; IEA 2014), and gives gross ranges for each of biogas upgrading technologies. The color code is the following: green is used for a characteristic that gives an specific advantage to the technology, especially in the context of downstream use of $\mathrm{CO}_{2}$ in the methanation process, and on the contrary orange is used for drawbacks. For instance $\mathrm{CO}_{2}$ outlet pressure after biogas upgrading can be around 1.8 bar (amines), which represents a relative benefit as there slightly less electricity is needed for $\mathrm{CO} 2$ compression before methanation compared to the other upgrading technologies. While water scrubbing technology is the favorite technology for biogas upgrading, one observes that the second preferred technology is the chemical absorption. For the latter process, the main drawback is the heat requirement at the regeneration step, a well-known drawback in the post-combustion carbon capture community (Steeneveldt et al. 2006). However, in the present case, where heat can be supplied by methanation, this drawback can easily be overcome, and even turned into an advantage. Similarly the methane loss of membrane technology is not anymore an issue since the $\mathrm{CO}_{2}$ containing some $\mathrm{CH}_{4}$ will be converted into $\mathrm{CH}_{4}$ at the methanation step. Furthermore, membrane technology is considered as the easiest to operate which can be a major advantage for such small size units for 
Table 2: Comparison of upgrading technologies.

\begin{tabular}{|c|c|c|c|c|}
\hline & Water Scrubber & $\begin{array}{l}\text { Pressure Swing } \\
\text { Adsorption }\end{array}$ & $\begin{array}{l}\text { Chemical absorption } \\
\text { (amines) }\end{array}$ & Membrane \\
\hline \multicolumn{5}{|l|}{ General characteristics } \\
\hline Electricity demand (kWh.m. $\left.{ }^{-3}{ }_{\mathrm{BG}}\right)$ & $0.2-0.3$ & $0.2-0.25$ & 0.15 & 0.25 \\
\hline Heat demand $\left({ }^{\circ} \mathrm{C}\right)$ & no & no & $120-160$ & no \\
\hline Operation pressure (bar) & $5-10$ & $4-7$ & 0.1 & $5-10$ \\
\hline Methane recovery (\%) & 98 & 98 & 99.96 & $80-99.5$ \\
\hline Methane content in upgraded gas (\%mol) & $>97$ & $>96$ & $>99$ & $>95$ \\
\hline Exhaust gas treatment & yes & yes & no & yes \\
\hline Water demand & yes $(+)$ & no & yes & no \\
\hline Demand on chemicals & no & no & yes & no \\
\hline Ease of operation & complex & intermediate & complex & easy \\
\hline Total costs $\left(€ / \mathrm{m}^{3}{ }_{\mathrm{CH} 4}\right)$ & 0.13 & 0.25 & $0.17-0.28$ & $0.12-0.22$ \\
\hline \multicolumn{5}{|l|}{ Number of units } \\
\hline number 2011 & 48 & 41 & 31 & 6 \\
\hline number 2013 & 113 & 58 & 61 & 27 \\
\hline \multicolumn{5}{|l|}{ Integration with methanation } \\
\hline Heat integration & No & No & Yes (similar $\Delta \mathrm{H})$ & No \\
\hline $\mathrm{CO}_{2}$ pressure & 1 & $<1$ & 1.8 & 1 \\
\hline
\end{tabular}

Amines scrubbing and membranes are thus the two different upgrading technologies that have been assessed in the present study. Chemical (amines) scrubbing corresponds to the formation of chemical bonds between the $\mathrm{CO}_{2}$ and a solvent, in general an aqueous solution of alcanolamines. Regeneration of the solvent is endothermic, and required heat is provided by burning part of the biogas or, preferentially in the present case, by the recovery of wasted heat from methanation when it is functioning. Monoethanolamine (MEA) has been considered for solvent since it is a well-known industrial solvent characterized as a highly reactive high energy requirement solvent. The first characteristic is in favor of low capital expenditures (CAPEX) while the second is in favor of high operational expenditures (OPEX) (Raynal et al. 2011). In the present case, since heat is available at methanation step, CAPEX optimization was thought more important than OPEX optimization. Ammonia and acetaldehyde emissions due to oxidative and thermal degradation of the solvents have been taken into account. In membranes separation, pressurized biogas is passed through a membrane which is selective for $\mathrm{CO}_{2}$. It is important to notice that depending on the chosen upgrading technology, $\mathrm{CH}_{4}$ content in the $\mathrm{CO}_{2}$ flow strongly varies. A scenario without biogas upgrading (direct methanation) is also assessed in this study. In all the cases previously described, a supplementary step of compression of the outputs of the upgrading process is needed before the methanation step. All the assumptions for biogas upgrading and compression steps are presented in

\section{Table 3.}

Table 3: Main assumptions at the biogas upgrading and compression steps

\begin{tabular}{|l|l|l|}
\hline Description & Values & Reference \\
\hline \multicolumn{2}{|c|}{ Amines scrubbing and $\mathrm{CO}_{2}$ compression } \\
\hline Inputs & $230 \mathrm{~m}^{3} \mathrm{~h}^{-1}$ & \\
\hline Biogas &
\end{tabular}




\begin{tabular}{|c|c|c|}
\hline Electricity consumption & $94.3{\mathrm{MJ} . \mathrm{h}^{-1}}^{-1}$ & Present data and (Starr et al. 2012) \\
\hline Heat consumption & $421{\mathrm{MJ} . \mathrm{h}^{-1}}^{-1}$ & Present data \\
\hline Water & $126 \mathrm{~kg} \cdot \mathrm{h}^{-1}$ & Present data \\
\hline MonoEthanolAmines & 11.5 g.h $\mathrm{h}^{-1}$ & $\begin{array}{l}\text { Present data and (Reiter \& Lindorfer } \\
\text { 2015) }\end{array}$ \\
\hline \multicolumn{3}{|l|}{ Outputs } \\
\hline $\mathrm{CO}_{2}$ outAmines & $\begin{array}{l}80 \mathrm{~m}^{3} \cdot \mathrm{h}^{-1} \\
\mathrm{CO}_{2}: 97.27 \% \mathrm{~mol} / \mathrm{H}_{2} \mathrm{O}: 2.73 \% \mathrm{~mol} \\
\mathrm{~T}: 150^{\circ} \mathrm{C} / \mathrm{P}: 13.3 \mathrm{bar}\end{array}$ & Present data \\
\hline $\mathrm{CH}_{4}$ outAmines & $\begin{array}{l}156 \mathrm{~m}^{3} \cdot \mathrm{h}^{-1} \\
\mathrm{CH}_{4}: 96.79 \% \mathrm{~mol} / \mathrm{CO}_{2}: 0.98 \% \mathrm{~mol} / \mathrm{H}_{2} \mathrm{O}: 2.23 \% \mathrm{~mol} \\
\mathrm{~T}: 50^{\circ} \mathrm{C} / \mathrm{P}: 5.6 \text { bar }\end{array}$ & Present data \\
\hline Ammonia & $16 \mathrm{~g} \cdot \mathrm{h}^{-1}$ & (Reiter \& Lindorfer 2015) \\
\hline Acetaldehyde & $423 \mathrm{~g} \cdot \mathrm{h}^{-1}$ & (Reiter \& Lindorfer 2015) \\
\hline \multicolumn{3}{|c|}{ Membranes and $\mathrm{CO}_{2}$ compression } \\
\hline \multicolumn{3}{|c|}{ ( } \\
\hline Biogas & $230 \mathrm{~m}^{3} \mathrm{~h}^{-1}$ & \\
\hline Electricity consumption & $152{\mathrm{MJ} . \mathrm{h}^{-1}}^{-1}$ & Present data \\
\hline \multicolumn{3}{|l|}{ Outputs } \\
\hline $\mathrm{CO}_{2}$ outMb & $\begin{array}{l}95.1 \mathrm{~m}^{3} \cdot \mathrm{h}^{-1} \\
\mathrm{CO}_{2}: 81.95 \% \mathrm{~mol} / \mathrm{CH}_{4}: 18.05 \% \mathrm{~mol} \\
\mathrm{~T}: 150^{\circ} \mathrm{C} / \mathrm{P}: 13.3 \mathrm{bar}\end{array}$ & Present data \\
\hline $\mathrm{CH}_{4}$ outMb & $\begin{array}{l}135 \mathrm{~m}^{3} \cdot \mathrm{h}^{-1} \\
\mathrm{CH}_{4}: 99.15 \% \mathrm{~mol} / \mathrm{CO}_{2}: 0.85 \% \mathrm{~mol} \\
\mathrm{~T}: 50^{\circ} \mathrm{C} / \mathrm{P}: 17 \mathrm{bar}\end{array}$ & Present data \\
\hline \multicolumn{3}{|c|}{ Direct: Biogas compression } \\
\hline \multicolumn{3}{|l|}{ Inputs } \\
\hline Biogas & $230 \mathrm{~m}^{3} \mathrm{~h}^{-1}$ & \\
\hline Electricity consumption & $108{\mathrm{MJ} . \mathrm{h}^{-1}}^{-1}$ & Present data \\
\hline \multicolumn{3}{|l|}{ Outputs } \\
\hline BiogasCompToMetha & $\begin{array}{l}225.5 \mathrm{~m}^{3} \mathrm{~h}^{-1} \\
\mathrm{CH}_{4}: 65.63 \% \mathrm{~mol} / \mathrm{CO}_{2}: 34.37 \% \mathrm{~mol} \\
\mathrm{~T}: 144^{\circ} \mathrm{C} / \mathrm{P}: 15.3 \mathrm{bar}\end{array}$ & Present data \\
\hline BiogasComp & $\begin{array}{l}4.5 \mathrm{~m}^{3} \mathrm{~h}^{-1} \\
\mathrm{CH}_{4}: 65.63 \% \mathrm{~mol} / \mathrm{CO}_{2}: 34.37 \% \mathrm{~mol} \\
\mathrm{~T}: 144^{\circ} \mathrm{C} / \mathrm{P}: 15.3 \mathrm{bar}\end{array}$ & Present data \\
\hline
\end{tabular}

\subsection{Electrolysis step}

181 Water electrolysis from renewable energy is a sustainable method for $\mathrm{H}_{2}$ production. It consists in 182 splitting water into $\mathrm{H}_{2}$ and oxygen $\left(\mathrm{O}_{2}\right)$. Inputs and outputs for this reaction are given in Table 4 . Two 183 main technologies are available on the market: alkaline or polymer electrolyte membrane (PEM) electrolysis. PEM water electrolysis is much more expensive, due to high capital cost of the cell stack compared to alkaline liquid electrolyte water electrolysis (Leng et al. 2012). On the other hand, intermittent operation of alkaline electrolysis is challenging (Reiter \& Lindorfer 2015). Nevertheless in the latest alkaline electrolysis technologies, operating on intermittent renewable electricity was found to be durable (Graves et al. 2011). Consequently we chose alkaline electrolysis in this study.

Table 4: Main assumptions at the electrolysis step

\begin{tabular}{|l|l|l|}
\hline Description & Values & Reference \\
\hline Inputs & $\begin{array}{l}252 \mathrm{~kg} . \mathrm{h}^{-1} \\
\mathrm{~T}: 15^{\circ} \mathrm{C} / \mathrm{P}: 1 \mathrm{bar}\end{array}$ & \\
\hline Tap water & $5634 \mathrm{MJ} \cdot \mathrm{h}^{-1}$ & $\begin{array}{l}\text { Present data based on DNV, (2013), Wang et al., } \\
\text { (2014) and Alphea, (2015) }\end{array}$ \\
\hline Electricity consumption & & \\
\hline
\end{tabular}




\begin{tabular}{|l|l|l|}
\hline Outputs & $312 \mathrm{~m}^{3} \cdot \mathrm{h}^{-1}$ \\
\hline $\mathrm{H}_{2}$ fromElectrolysis & $\begin{array}{l}\text { Present data based on DNV, (2013), Wang et al., } \\
\text { (2014) and Alphea, (2015) }\end{array}$ \\
\hline $\mathrm{O}_{2}$ fromElectrolysis & $156.5 \mathrm{~m}^{\circ} \mathrm{C}: \mathrm{h}^{-1}$ & $\begin{array}{l}\text { Present data based on DNV, (2013), Wang et al., } \\
\text { (2014) and Alphea, (2015) }\end{array}$ \\
\hline
\end{tabular}

\subsection{Methanation step}

191 Methanation consists in synthetizing $\mathrm{CH}_{4}$ from $\mathrm{CO}_{2}$ and $\mathrm{H}_{2}$ (Sabatier reaction):

$1924 \mathrm{H}_{2}+\mathrm{CO}_{2} \rightarrow \mathrm{CH}_{4}+2 \mathrm{H}_{2} \mathrm{O}$.

193 In this study, $\mathrm{H}_{2}$ comes from water electrolysis, and $\mathrm{CO}_{2}$ is supplied by two ways: as almost pure $\mathrm{CO}_{2}$

194 from upgrading step (by amine scrubbing or membrane separation), or mixed with $\mathrm{CH}_{4}$ in the direct

195 methanation scenario. Methanation can be done by chemical or biological catalysis (Burkhardt \&

196 Busch 2013). In this study, fixed-bed technology is used, with chemical catalysts mainly composed of

197 nickel (Ocampo et al. 2009; Wang et al. 2011). Methanation reaction is exothermic, with a heat

198 production of $0.165 \mathrm{MJ}^{-m^{-1}}$ of input $\mathrm{CO}_{2}$ (Hoekman et al. 2010). Produced heat is used to

199 regenerate the solvent in biogas upgrading by amines scrubbing and / or to heat the anaerobic

200 digesters. Required data are presented in Table 5, and are in line with recent work of Reiter and

201 Lindorfer (2015).

Table 5: Main assumptions at the methanation step

\begin{tabular}{|c|c|c|}
\hline Description & Values & Reference \\
\hline \multicolumn{3}{|c|}{$\mathrm{CO}_{2}$ from amines scrubbing } \\
\hline \multicolumn{3}{|l|}{ Inputs } \\
\hline $\mathrm{CO}_{2}$ outAmines & $80 \mathrm{~m}^{3} \cdot \mathrm{h}^{-1}$ & \\
\hline Electricity consumption & $27.2{\mathrm{MJ} . \mathrm{h}^{-1}}^{-1}$ & Present data \\
\hline $\mathrm{H}_{2}$ fromElectrolysis & $310.2 \mathrm{~m}^{3} \cdot \mathrm{h}^{-1}$ & Present data \\
\hline \multicolumn{3}{|l|}{ Outputs } \\
\hline $\mathrm{CH}_{4}$ outMethaAmines & $\begin{array}{l}80 \mathrm{~m}^{3} \cdot \mathrm{h}^{-1} \\
\mathrm{CH}_{4}: 96.56 \% \mathrm{~mol} / \mathrm{H}_{2}: 1.69 \% \mathrm{~mol} / \mathrm{H}_{2} \mathrm{O}: \\
1.33 \% \mathrm{~mol} / \mathrm{CO}_{2}: 0.80 \% \mathrm{~mol} \\
\mathrm{~T}: 50^{\circ} \mathrm{C} / \mathrm{P}: 9.5 \mathrm{bar}\end{array}$ & Present data \\
\hline HeatoutMethaAmines & $615.9{\mathrm{MJ} . \mathrm{m}^{-3} \mathrm{CO}_{2} \text { outAmines }}$ & Present data \\
\hline \multicolumn{3}{|c|}{$\mathrm{CO}_{2}$ from membranes } \\
\hline \multicolumn{3}{|l|}{ Inputs } \\
\hline $\mathrm{CO}_{2} \mathrm{OutMb}$ & $95.1 \mathrm{~m}^{3} \cdot \mathrm{h}^{-1}$ & \\
\hline Electricity consumption & $33.3{\mathrm{MJ} . \mathrm{h}^{-1}}^{-1}$ & Present data \\
\hline $\mathrm{H}_{2}$ fromElectrolysis & $312 \mathrm{~m}^{3} \cdot \mathrm{h}^{-1}$ & Present data \\
\hline \multicolumn{3}{|l|}{ Outputs } \\
\hline $\mathrm{CH}_{4}$ outMethaMb & $\begin{array}{l}98 \mathrm{~m}^{3} \cdot \mathrm{h}^{-1} \\
\mathrm{CH} 4: 96.7 \% \mathrm{~mol} / \mathrm{H}_{2}: 1.2 \% \mathrm{~mol} / \mathrm{H}_{2} \mathrm{O}: \\
1.1 \% \mathrm{~mol} / \mathrm{CO}_{2}: 0.3 \% \mathrm{~mol} \\
\mathrm{~T}: 50^{\circ} \mathrm{C} / \mathrm{P}: 9.5 \text { bar }\end{array}$ & Present data \\
\hline HeatoutMethaMb & 721 MJ.h $^{-1}$ & Present data \\
\hline \multicolumn{3}{|c|}{ Biogas } \\
\hline \multicolumn{3}{|l|}{ Inputs } \\
\hline BiogasCompToMetha & $225.5 \mathrm{m3} . \mathrm{h}^{-1}$ & \\
\hline Electricity consumption & 106 MJ.h $^{-1}$ & Present data \\
\hline $\mathrm{H}_{2}$ fromElectrolysis & $310.2 \mathrm{~m}^{3} \cdot \mathrm{h}^{-1}$ & Present data \\
\hline \multicolumn{3}{|l|}{ Outputs } \\
\hline $\mathrm{CH}_{4}$ outMethaBiogas & $\begin{array}{l}230.9 \mathrm{~m}^{3} \mathrm{~h}^{-1} \\
\mathrm{CH}_{4}: 97.4 \% \mathrm{~mol} / \mathrm{H}_{2}: 1.6 \% \mathrm{~mol} / \mathrm{H}_{2} \mathrm{O}: \\
1.3 \% \mathrm{~mol} / \mathrm{CO}_{2}: 0.4 \% \mathrm{~mol}\end{array}$ & Present data \\
\hline
\end{tabular}




\begin{tabular}{|l|l|l|}
\hline & $\mathrm{T}: 50^{\circ} \mathrm{C} / \mathrm{P}: 9.5$ bar & \\
\hline HeatoutMethaBiogas & $586.3 \mathrm{MJ} . \mathrm{m}^{-3}$ Biogas & Present data \\
\hline
\end{tabular}

\subsection{Completion, injection and combustion steps}

Before injecting the bioCH $\mathrm{CH}_{4}$ in the natural gas network, a completion step is necessary in order to bring the dew point to existing specifications (here $40^{\circ} \mathrm{C}$ and 5 bar). Electricity consumptions of this operation for the three proposed scenarios are given in Table 6.

Table 6: Main assumptions at the completion step

\begin{tabular}{|c|c|c|}
\hline Description & Values & Reference \\
\hline \multicolumn{3}{|c|}{$\mathrm{CH}_{4}$ from $\mathrm{CO}_{2}$ amines } \\
\hline \multicolumn{3}{|l|}{ Inputs } \\
\hline $\mathrm{CH}_{4}$ outMethaAmines $+\mathrm{CH}_{4}$ outAmines & $80 m^{3} h^{-1}+156 m^{3} h^{-1}$ & \\
\hline Electricity consumption for completion & $47.2{\mathrm{MJ} . \mathrm{h}^{-1}}^{-1}$ & Present data \\
\hline \multicolumn{3}{|l|}{ Outputs } \\
\hline $\mathrm{CH}_{4}$ CompletionAmines & $\begin{array}{l}232 \mathrm{~m}^{3} \mathrm{~h}^{-1} \\
\mathrm{CH}_{4}: 98.54 \% \mathrm{~mol} / \mathrm{H}_{2}: 0.58 \% \mathrm{~mol} / \\
\mathrm{CO}_{2}: 0.80 \% \mathrm{~mol} / \mathrm{H}_{2} \mathrm{O}: 0.08 \% \mathrm{~mol} \\
\mathrm{~T}: 40^{\circ} \mathrm{C} / \mathrm{P}: 5 \mathrm{bar}\end{array}$ & Present data \\
\hline \multicolumn{3}{|c|}{$\mathrm{CH}_{4}$ from $\mathrm{CO}_{2}$ membranes } \\
\hline \multicolumn{3}{|l|}{ Inputs } \\
\hline $\mathrm{CH}_{4}$ outMethaMb $+\mathrm{CH}_{4}$ outMb & $98 m^{3} h^{-1}+135 m^{3} h^{-1}$ & \\
\hline Electricity consumption for completion & $37.3{\mathrm{MJ} . \mathrm{h}^{-1}}$ & Present data \\
\hline \multicolumn{3}{|l|}{ Outputs } \\
\hline $\mathrm{CH}_{4}$ CompletionMb & $\begin{array}{l}232 \mathrm{~m}^{3} \mathrm{~h}^{-1} \\
\mathrm{CH}_{4}: 98.58 \% \mathrm{~mol} / \mathrm{H}_{2}: 0.68 \% \mathrm{~mol} / \\
\mathrm{CO}_{2}: 0.66 \% \mathrm{~mol} / \mathrm{H}_{2} \mathrm{O}: 0.08 \% \mathrm{~mol} \\
\mathrm{~T}: 40^{\circ} \mathrm{C} / \mathrm{P}: 5 \mathrm{bar}\end{array}$ & Present data \\
\hline \multicolumn{3}{|c|}{$\mathrm{CH}_{4}$ from Biogas } \\
\hline \multicolumn{3}{|l|}{ Inputs } \\
\hline $\mathrm{CH}_{4}$ outMethaBiogas $+\mathrm{CH}_{4}$ outBiogas & $230.9 \mathrm{~m}^{3} \mathrm{~h}^{-1}+4.5 \mathrm{~m}^{3} \mathrm{~h}^{-1}$ & \\
\hline Electricity consumption for completion & $40{\mathrm{MJ} . \mathrm{h}^{-1}}^{-1}$ & Present data \\
\hline \multicolumn{3}{|l|}{ Outputs } \\
\hline $\mathrm{CH}_{4}$ CompletionBiogas & $\begin{array}{l}233 \mathrm{~m}^{3} \mathrm{~h}^{-1} \\
\mathrm{CH}_{4}: 97.8 \% \mathrm{~mol} / \mathrm{H}_{2}: 1.15 \% \mathrm{~mol} / \mathrm{CO}_{2}: \\
0.97 \% \mathrm{~mol} / \mathrm{H}_{2} \mathrm{O}: 0.08 \% \mathrm{~mol} \\
\mathrm{~T}: 40^{\circ} \mathrm{C} / \mathrm{P}: 5 \mathrm{bar}\end{array}$ & Present data \\
\hline
\end{tabular}

At last, data for injection and combustion have been directly taken from the Ecoinvent 2.2 database, with biogenic $\mathrm{CO}_{2}$ emissions instead of fossil $\mathrm{CO}_{2}$ emissions. .

\subsection{Economic data}

In Table 7, operating expenditure (OPEX) and capital expenditure (CAPEX) for all the processes are presented. OPEX corresponding here to electricity consumption can be calculated from previous tables, and for different electricity prices. CAPEX of each process (upgrading, electrolysis, methanation and injection) have been evaluated by IFPEN and are specific results of this study. The capital cost estimations have been assumed to be in the range of $-30 \% /+50 \%$.

Since the biogas production process has not been modeled from an economic point of view, the biogas production price has been estimated. We have supposed that biomethane injection in the 
network allows an internal rate of return (IRR) equal to $10 \%$ on 15 years. Given the feed-in tariffs of

bioCH4 - fixed by decree in France in 2014

221 (http://www.legifrance.gouv.fr/affichTexte.do?cidTexte=JORFTEXT000024833895) and taking into account the costs of the final steps - biogas upgrading and injection - this leads to a biogas production cost equal to $0.36 € \cdot m-3$.

Table 7: Main assumptions for the CAPEX and the OPEX

\begin{tabular}{|c|c|c|c|c|}
\hline \multicolumn{2}{|l|}{ Process } & OPEX & CAPEX & References \\
\hline \multicolumn{2}{|l|}{ Biogas } & $0.36 € . \mathrm{m}^{-3}$ Biogas & - & \\
\hline \multicolumn{2}{|l|}{ Electrolysis } & $\begin{array}{l}\text { Electricity consumption }+ \\
100 \text { k€.year }^{-1} \text { for maintenance }\end{array}$ & $1000 € . \mathrm{kW}^{-1}$ & $\begin{array}{l}\text { Present data based on DNV, (2013), ADEME, (2014), } \\
\text { IEA, (2015) and Götz et al. (2016) }\end{array}$ \\
\hline \multirow[t]{2}{*}{ Amines } & Separation & $\begin{array}{l}\text { Electricity consumption }+ \\
0.8 € . \text { hour }^{-1}\end{array}$ & $\begin{array}{l}1050 \mathrm{k} € \text {, i.e } \\
4570 € /\left(\mathrm{m}^{3} \cdot \mathrm{h}^{-1}\right)\end{array}$ & $\begin{array}{l}\text { Present data, in line with } 5000 € /\left(\mathrm{m}^{3} \cdot \mathrm{h}^{-1}\right) \text { (Bauer et } \\
\text { al., } 2013 \text { and TUV, 2012) for a capacity of } 250 \mathrm{~m}^{3} \cdot \mathrm{h}^{-1}\end{array}$ \\
\hline & Methanation & $\begin{array}{l}\text { Electricity consumption }+ \\
6.2 € . \text { hour }^{-1}\end{array}$ & $400 \mathrm{k} €$ & Present data, in line with Götz et al. (2016) \\
\hline \multirow[t]{2}{*}{ Membranes } & Separation & $\begin{array}{l}\text { Electricity consumption }+ \\
1.7 € . \text { hour }^{-1}\end{array}$ & $\begin{array}{l}750 \mathrm{k} € \text {, i.e } \\
3260 € /\left(\mathrm{m}^{3} \cdot \mathrm{h}^{-1}\right)\end{array}$ & $\begin{array}{l}\text { Present data, in line with } 3200 € /\left(\mathrm{m}^{3} \cdot \mathrm{h}^{-1} \text { ) (Bauer et }\right. \\
\text { al., 2013) for a capacity of } 250 \mathrm{~m}^{3} \cdot \mathrm{h}^{-1}\end{array}$ \\
\hline & Methanation & $\begin{array}{l}\text { Electricity consumption }+ \\
12.4 € \text { hour }^{-1}\end{array}$ & $650 \mathrm{k€}$ & Present data, in line with Götz et al. (2016) \\
\hline \multicolumn{2}{|c|}{ Direct methanation } & $\begin{array}{l}\text { Electricity consumption + } \\
14.1 € . \text { hour }^{-1}\end{array}$ & $650 \mathrm{k€}$ & Present data, in line with Götz et al. (2016) \\
\hline \multicolumn{2}{|l|}{ Injection } & 100 k€.year ${ }^{-1}$ & $130 \mathrm{k} €$ & $\begin{array}{l}\text { Present data based on DNV, (2013), ADEME, (2014) } \\
\text { and IEA, (2015) }\end{array}$ \\
\hline
\end{tabular}

\section{Results}

\subsection{Economic results}

\section{Continuous operation}

228 Annualized production costs of can be seen on Figure 2, for an electricity price of $30 € . \mathrm{MWh}^{-1}$ and

229 with an IRR equal to $10 \%$ on 15 years. There is an important difference of total annualized production 230 costs with and without methanation: approximatively $1650 \mathrm{k€}$.year ${ }^{-1}$ for upgrading with PtG, and 940 231 k€.year ${ }^{-1}$ for standard upgrading. The largest contribution to the production costs is the biogas 232 production, (around $80 \%$ for upgrading technologies and $45 \%$ for PtG scenarios). This cost is the 233 same in the five scenarios assessed $\left(757 \mathrm{k} . \mathrm{year}^{-1}\right)$, but as total production costs are much higher in 234 the methanation scenarios, the contribution of biogas is lower. The higher costs of the methanation 235 scenarios are mainly due to the electrolysis step. It represents more than $35 \%$ of the production 236 costs, with a large share due to electricity consumption (70\% of the electrolysis costs). At last for PtG 237 production with $\mathrm{CH}_{4}$ and $\mathrm{CO}_{2}$ separation, upgrading and methanation costs are quite similar. 


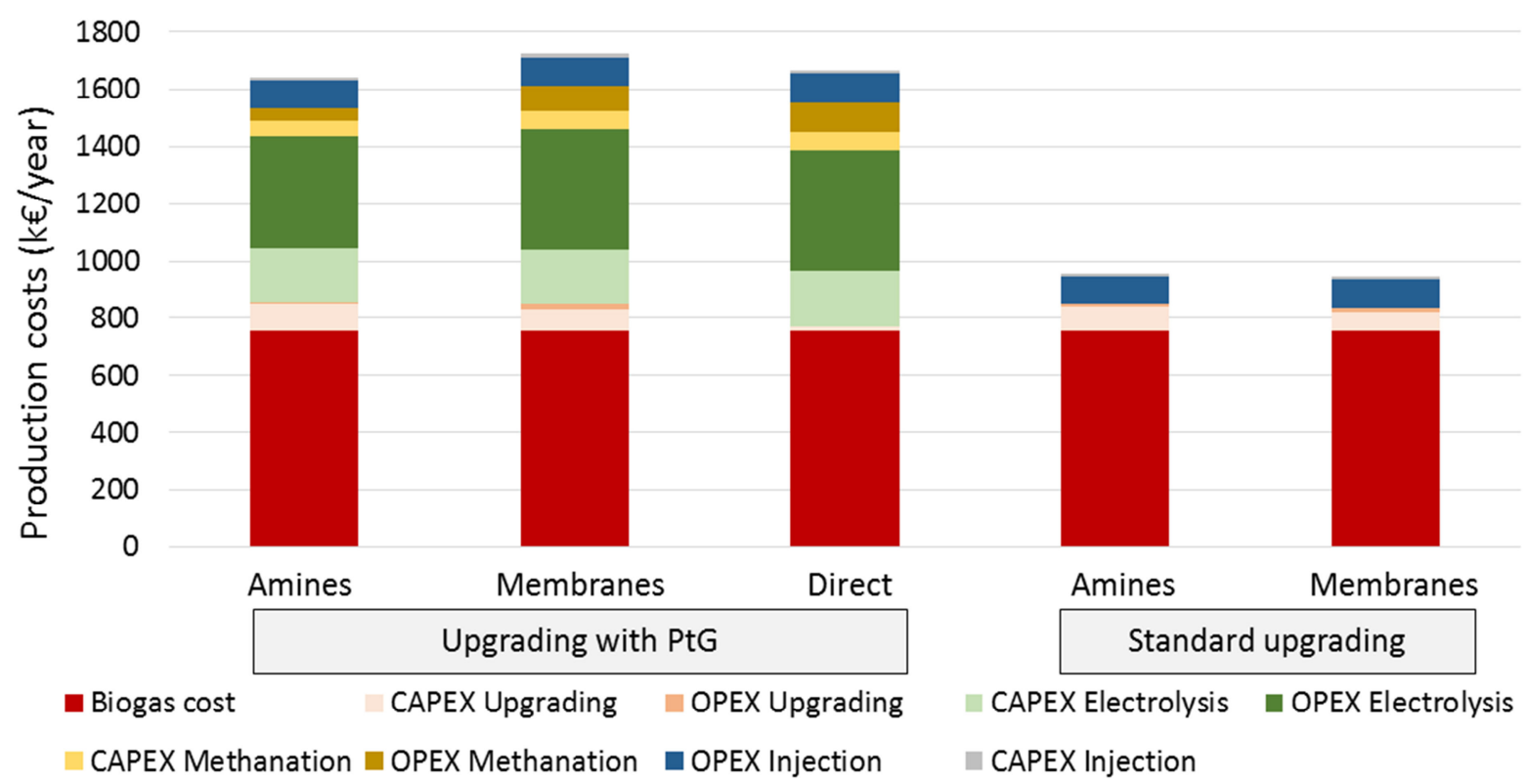

Figure 2: Contribution analysis of the annualized production costs

The contribution analysis of the production costs for $1 \mathrm{kWh}$ of bio $\mathrm{CH}_{4}$ from PtG or upgrading are shown on Figure 3, for the same electricity price and IRR rate than the Figure 2. It appears that production costs of the different options are quite the same: they range from a minimum of 0.096 $€ . \mathrm{kWh}^{-1}$ for PtG from biogas with direct methanation and with membrane separation, and a maximum of $0.104 € . \mathrm{kWh}^{-1}$ for biogas upgrading with membrane separation. In fact, the higher production cost of the PtG technologies are counterbalanced by a higher bio $\mathrm{CH}_{4}$ injection in the gas network ( $41 \mathrm{~m}^{3} \cdot \mathrm{h}^{-1}$ on average for standard upgrading versus $138 \mathrm{~m}^{3} \cdot \mathrm{h}^{-1}$ on average for methanation scenarios). The respective contributions of the different steps are the same than for the annualized production costs. 


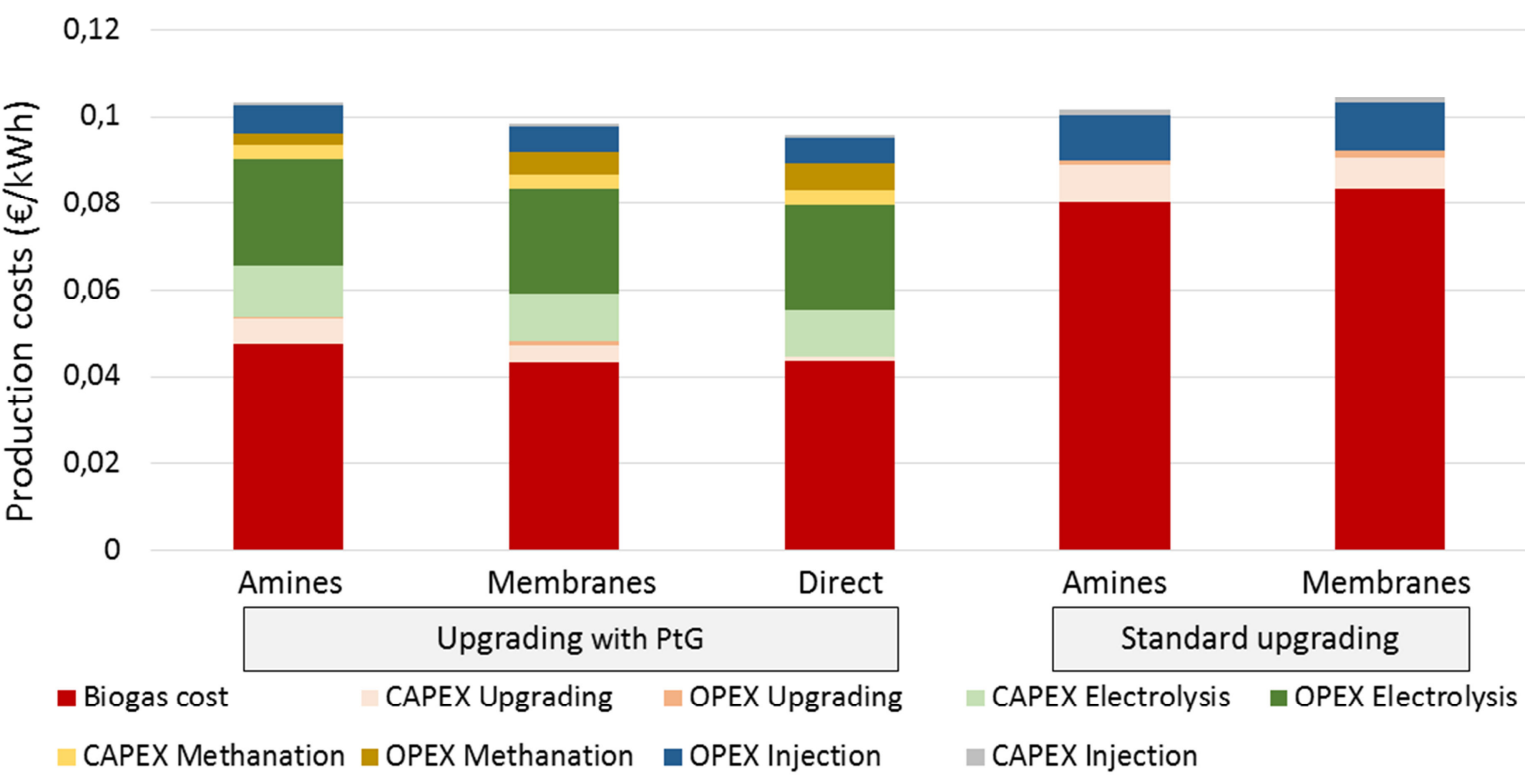

Figure 3: Contribution analysis of the production costs for $1 \mathrm{kWh}$ injected in the gas network

252 In Figure 4, overall production costs of the different scenarios are presented for electricity prices 253 ranging from 0 to $45 € \cdot \mathrm{MWh}^{-1}$. Costs of $\mathrm{CH}_{4}$ from upgrading technologies are almost insensitive to 254 electricity price, as they are mainly driven by the fixed biogas cost, and because the only other relevant OPEX corresponds to the injection step which is not correlated with the electricity price (see Table 7). On the contrary, PtG scenarios are very sensitive to the electricity price, with an increase of approximatively $35 \%$ of the production costs, mainly because of the electricity consumption at the electrolysis step. Compared to production of $\mathrm{CH}_{4}$ with the cheaper upgrading technology (amines scrubbing), $\mathrm{CH}_{4}$ from PtG is competitive for electricity price below $27 € . \mathrm{MWh}^{-1}$ for separation with amines scrubbing, below $34 € . \mathrm{MWh}^{-1}$ with separation by membranes and below $38 €$ €.MWh${ }^{-1}$ for direct methanation.

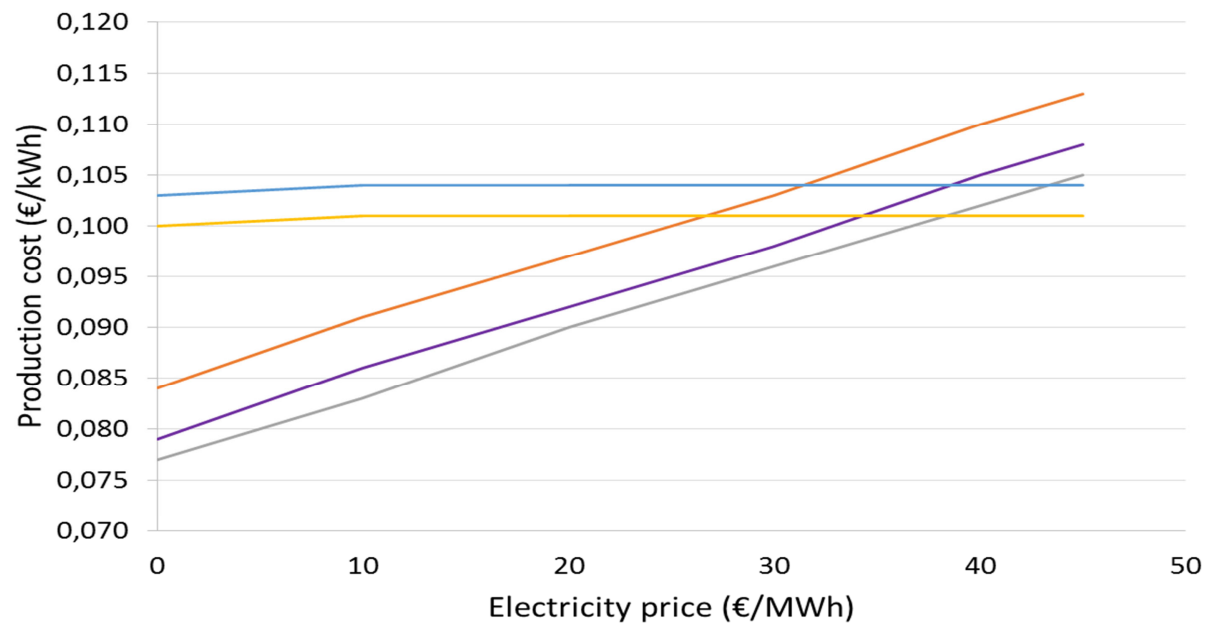


As previously pointed out, PtG can be seen as a relevant way to store overproduced electricity, and then intermittent operation should also be analyzed. According to Gahleitner (2013) the use of such fluctuating power sources is satisfying, and is currently in use in a lot of PtG pilot plants. Economic results for operation time varying between 2000 and 8760 hours (continuous operation) have been assessed for PtG scenarios and $\mathrm{CH}_{4}$ from amines scrubbing (Figure 5), with an electricity price equal to $20 € . \mathrm{MWh}^{-1}$. Biogas upgrading is insensitive to the operation time. This can be explained by the important contribution of the biogas production, and because others OPEX are almost exclusively driven by the fixed cost of the rental of the injection station. On the opposite, costs of direct methanation are very strongly connected with the operation time, with costs between $0.330 € . \mathrm{kWh}^{-1}$ for 2000 hours of operating time, and $0.090 € . \mathrm{kWh}^{-1}$ for continuous operation. In fact in this configuration $\mathrm{CH}_{4}$ contained in the biogas is not recovered and injected in the gas grid when methanation is not in operation. Consequently, the volume of energy produced is drastically reduced with the increase of the intermittency. On the other hand, fixed costs (biogas production, all the CAPEX and rental of the injection unit) are unchanged. Therefore the direct methanation leads to a dramatic increase of the production costs with an intermittent functioning, and so this technology is not suitable for non-continuous operation mode. Finally, like in the direct methanation, production costs decrease for membranes and amines technologies of PtG with the increase of the operation, but to a much lesser degree. Depending of the duration of the operation time, and for a given price of electricity, production costs can be higher or lower than $\mathrm{CH}_{4}$ from biogas upgrading. For instance, for a electricity at $20 € . \mathrm{MWh}^{-1}$, operation time should be at least equal to 6160 hours for membranes separation and to 7240 hours for amines separation to be competitive with biogas upgrading. 


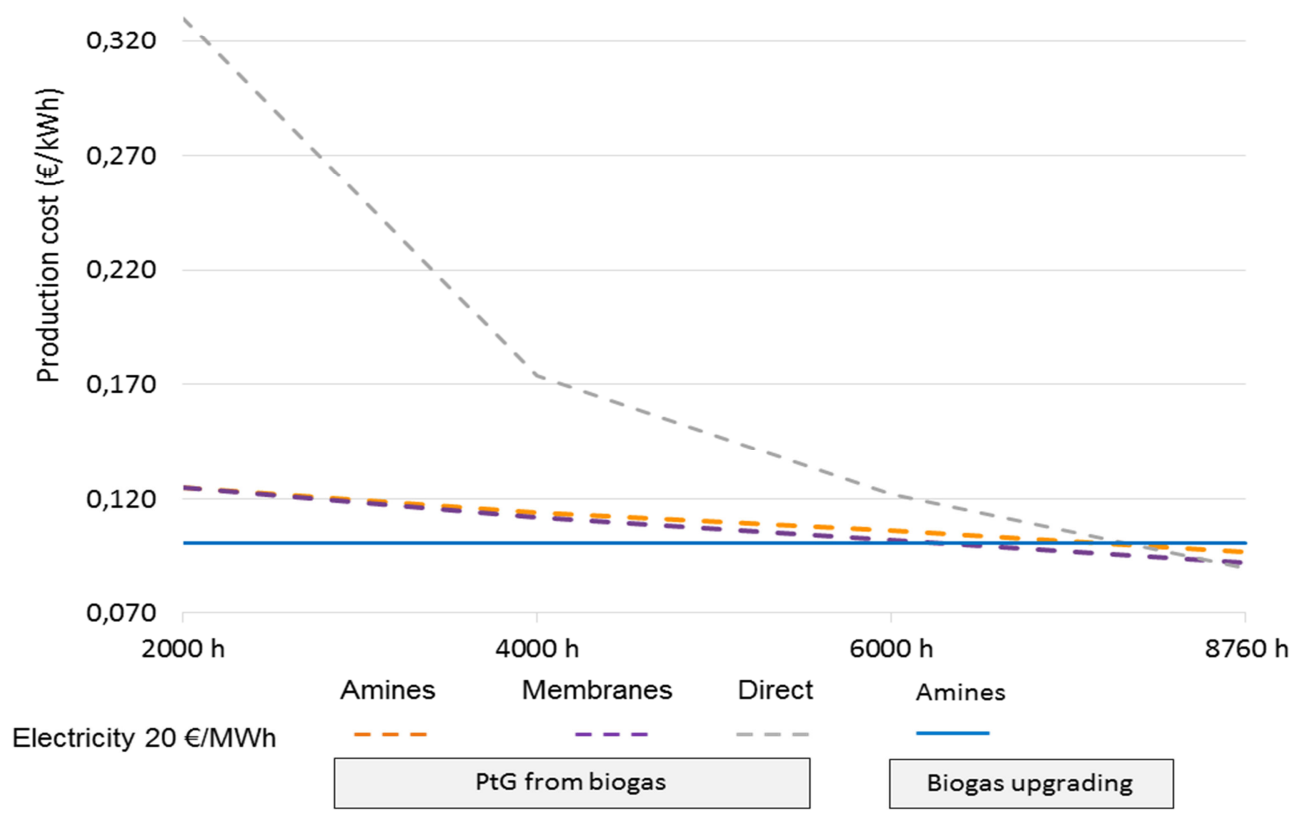
operating time

Combined effect of electricity price and operation time have also been assessed (Figure 6). upgrading can strongly vary. For instance, for a free electricity, operation time should be at least equal to 4445 hours for membranes separation and to 5232 hours for amines separation to be competitive with biogas upgrading. It means that the methanation unit should be in operation at least almost 4500 hours to counterbalance the fixed costs and the CAPEX. At last, with an electricity price equal to $45 € . \mathrm{MWh}^{-1}$, PtG technologies cannot compete with biogas upgrading. We also clearly see on Figure 6 that the operation cost difference between PtG from amines and from membranes increase with the operation time. 


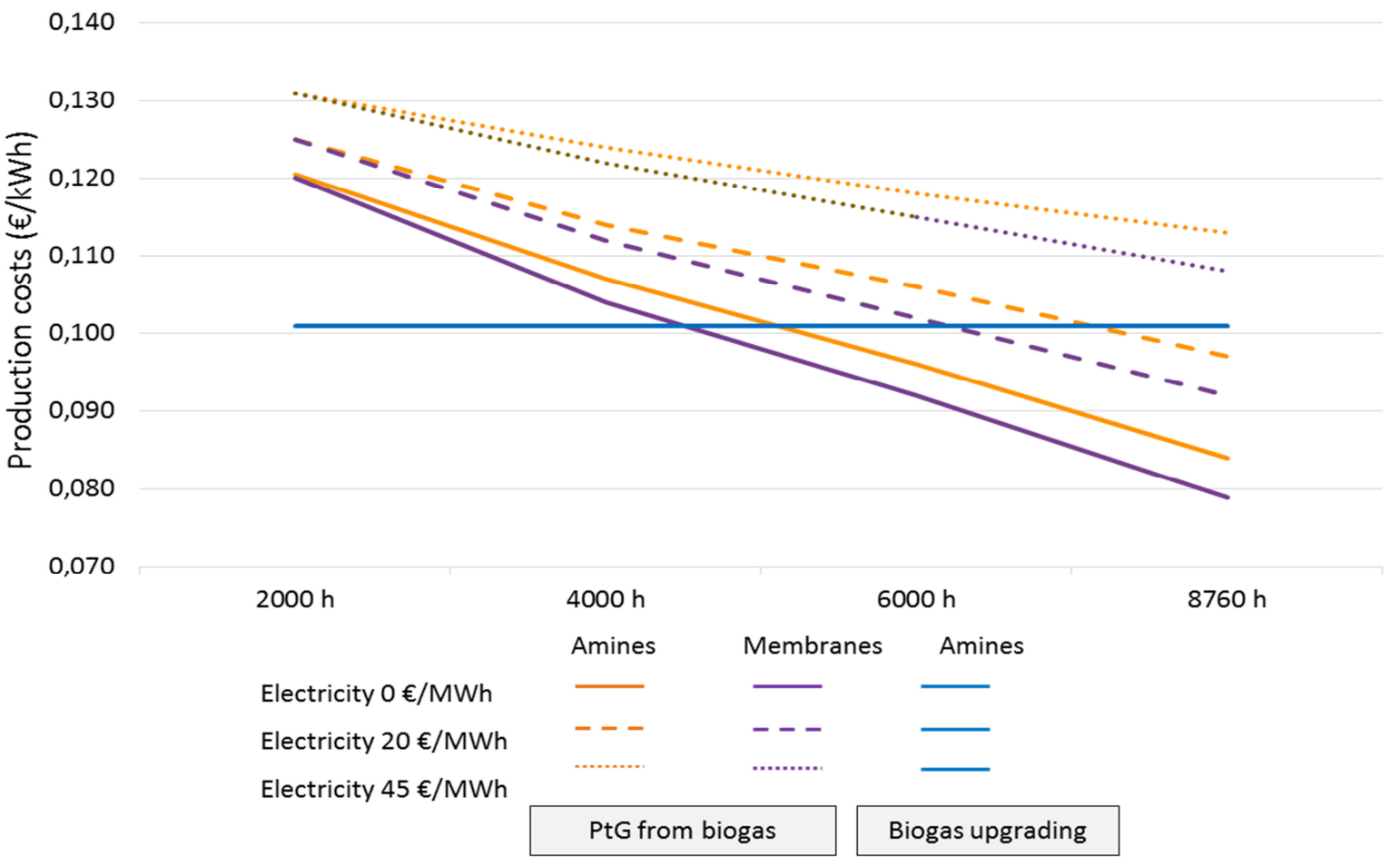

Figure 6: Productions costs for $1 \mathrm{kWh}$ injected in the gas network depending on the price of electricity and the operating time

Sensitivity analysis

As it has been underlined in the contribution analysis, electrolysis and more precisely the electricity consumption of this step, is one of the main contributor to the production costs of $\mathrm{CH}_{4}$ from PtG. Thus, we conduct a sensitivity analysis on the electricity consumption for $\mathrm{H}_{2}$ production. We discuss a favorable scenario, with a reduction of $25 \%$ of the electricity consumption (i.e $3.75 \mathrm{kWh} . \mathrm{m}^{-3} \mathrm{H}_{2}$ ). This value is in line with predicted values of future electricity consumptions around $3 \mathrm{kWh} \cdot \mathrm{m}^{-3} \mathrm{H}_{2}$ (Udagawa et al. 2007; Zeng \& Zhang 2010). The evolution of production costs with low electricity consumption scenarios and for different electricity prices is shown on Figure 7. As expected, the more electricity is expensive, the more electricity consumption reduction has an important effect on the diminution of the production costs. For a price of electricity of $10 € . \mathrm{MWh}^{-1}$, the decrease of the production cost is only equal to $0.001 € . \mathrm{KWh}^{-1}$, but with an electricity at $45 € . \mathrm{MWh}^{-1}$, the reduction of

313 the production cost is equal to $0.007 € . \mathrm{kWh}^{-1}$. Consequently, the minimum price of electricity so that $314 \mathrm{CH}_{4}$ from PtG can be competitive with $\mathrm{CH}_{4}$ from upgrading increases: it reaches $35 € . \mathrm{MWh}^{-1}$ for amines scrubbing and is around $45 € . \mathrm{MWh}^{-1}$ for membranes separation. 


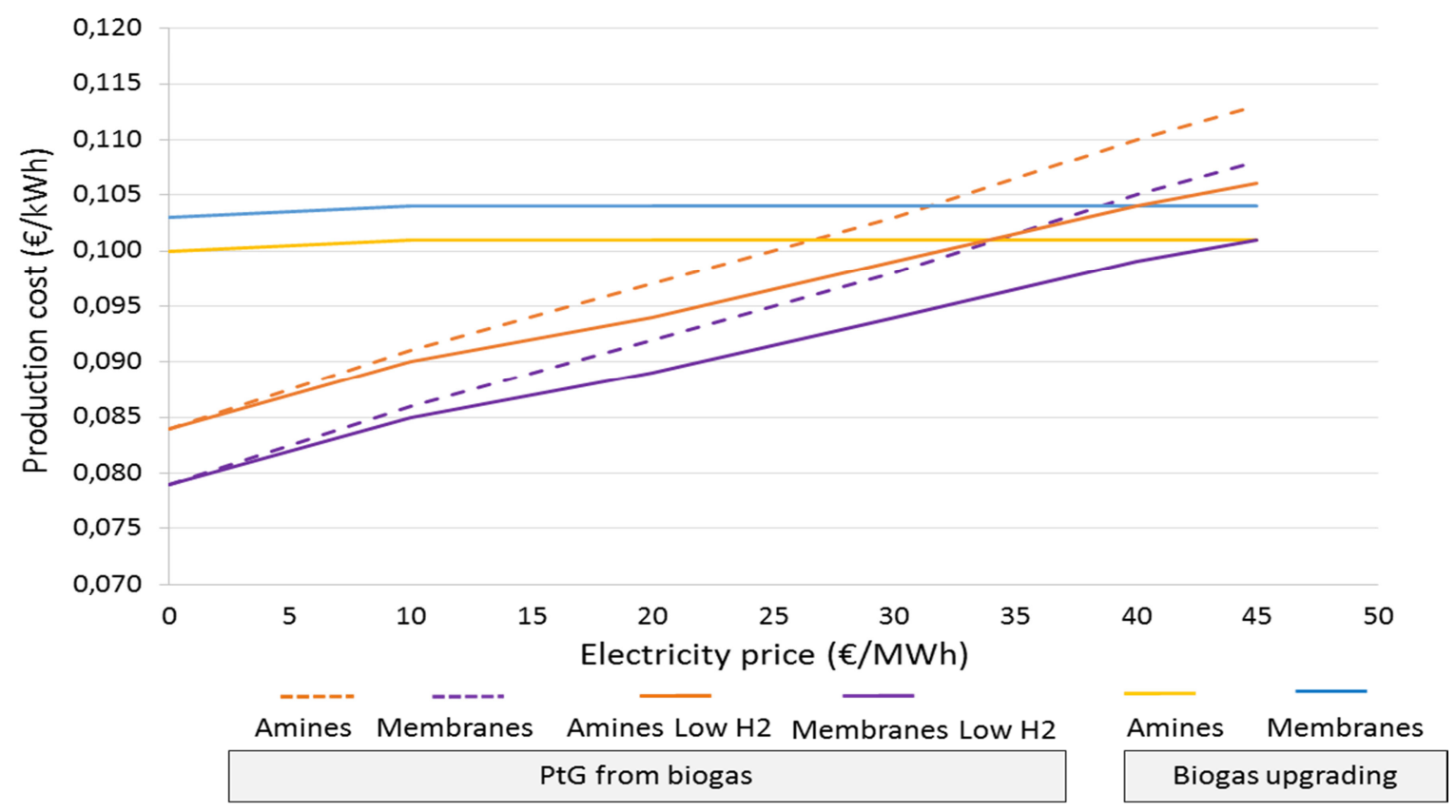

Figure 7: Productions costs for $1 \mathrm{kWh}$ injected in the gas network depending on the price of electricity and the electricity consumption for $\mathrm{H}_{2}$ production

\subsection{Environmental impacts}

322 Environmental impacts of the study have been assessed within the methodological framework of the

323 LCA based on a "cradle to grave" inventory of emissions and resources consumption. The considered 324 functional unit in the study is one MJ produced by combustion of $\mathrm{CH}_{4}$ in a boiler, based on the lower 325 heating value of $\mathrm{CH}_{4}\left(50.0 \mathrm{MJ} \cdot \mathrm{kg}^{-1}\right)$. As one of the main objective is to reduce $\mathrm{GHG}$ emissions in the atmosphere with respect to fossil fuels, we therefore consider the climate change impact. It has been assessed with the characterization factors provided by the fourth IPCC report for a temporal horizon of 100 years (IPCC 2007). It should be underlined that the characterization factor of $\mathrm{CH}_{4}$ in case of methane loss has to be adapted. Since the carbon of the $\mathrm{CH}_{4}$ comes from the sewage sludge (and previously from the atmosphere), the characterization factor must be the one of biogenic $\mathrm{CH}_{4}$, which is slightly below the one of the fossil $\mathrm{CH}_{4}\left(22.3 \mathrm{~kg} \mathrm{CO}{ }_{2}\right.$ eq. $\mathrm{kg}^{-1}$ vs. $25 \mathrm{~kg} \mathrm{CO}_{2}$ eq.kg $\left.{ }^{-1}\right)$.

332 As recommended in The Renewable Energy Directive (Parliament 2009), upstream impacts of sewage sludge are not taken into account. The same approach has been applied on LCA of sewage sludge valorization (Sadhukhan 2014; Yoshida et al. 2013). The substitution method has been used for digestates accounting, in accordance with the ISO guidelines, which suggest to choose the substitution instead of the allocation when it is possible. It corresponds to an expansion of the system boundaries in order to consider the impacts engendered by the by-products. Therefore, the use of digestates as fertilizers are supposed to save the equivalent amount of mineral fertilizers for N, P and K. In Figure 8, Figure 9 and Figure 11, the legend "digestates substitution" corresponds to 
this environmental credit, and "digestates emissions" to the emissions at the biogas plant and at the

341 field.

\section{Continuous operation}

343 Principal contributors to GHG emissions for the different assessed technologies are shown on Figure

344 8. From a global perspective, GHG emissions from PtG are almost equivalent for the three 345 technologies, and higher than biogas upgrading. Nevertheless, they are still lower than GHG emissions from natural gas combustion. For the fossil scenario (natural gas burned in a boiler), most of the emissions correspond to fossil $\mathrm{CO}_{2}$ from gas combustion. The remaining emissions are linked to resource extraction and transportation of the gas in the pipelines. In the scenarios with production of energy from sewage sludge, main GHG emissions come from the management of the digestates. Environmental burdens are associated with loss of $\mathrm{CH}_{4}(40 \%)$ and emissions of $\mathrm{N}_{2} \mathrm{O}(60 \%)$. On the other hand, negative impacts are due to the substitution of the digestates to the production and the use of mineral fertilizers. For PtG technologies, electricity consumption is also an important contributor to climate change. As the carbon content of the French electricity is particularly low due to the large part of the nuclear in the mix composition, a sensitivity analysis on the source of electricity (and as a consequence on its carbon content) is done in a following paragraph.

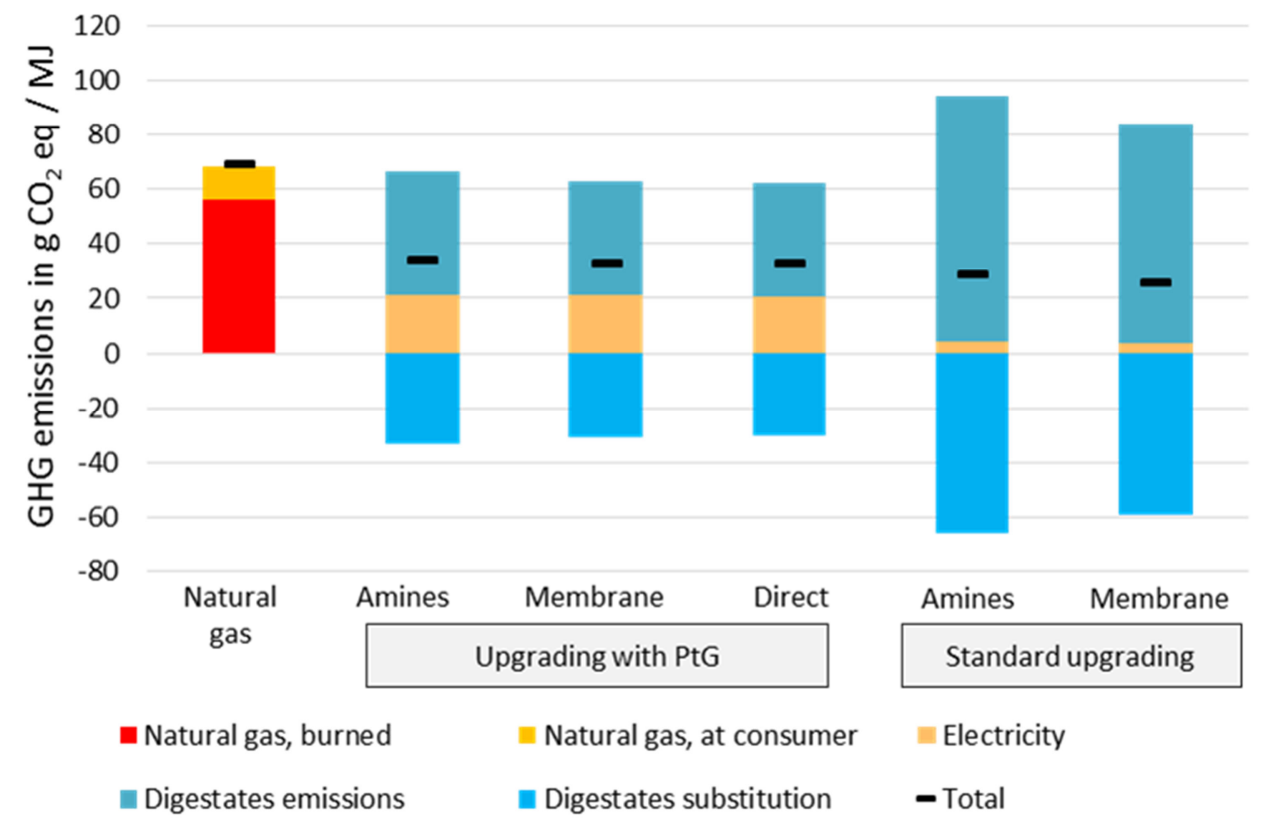
Intermittent operation overproduction occurrence was estimated at $28 \%$ of the year for $2020,36 \%$ in 2030 and $41 \%$ in 2050 , 
electricity surplus is $80 \%$ renewable and $20 \%$ nuclear by 2050 . Figure 9 presents results for intermittent methanation during overproduction period. It is supposed that when methanation is not functioning, the non-injected gas $\left(\mathrm{CO}_{2}\right.$ with $18 \%$ of $\mathrm{CH}_{4}$ in membrane separation and biogas with $65 \%$ of $\mathrm{CH}_{4}$ in direct methanation) is flared, in order to reduce direct $\mathrm{CH}_{4}$ emissions to the atmosphere. In this scenario, the results for membrane and amines separation are almost the same, so only amine technology will be represented for the next environmental impact assessment results. In direct technology configuration, biogas is not recovered and injected in the gas grid when methanation is not in operation, like in the economic assessment. This leads to GHG emissions which are much higher than continuous operation (and even higher than natural gas combustion) for the three time horizons analyzed. On the contrary, intermittent operation with electricity from renewable resources and amines separation leads to an important decrease compared to continuous operation with French average electricity mix (-37\% in 2020 and $-40 \%$ in 2050). For the three scenarios assessed, climate change impact of PtG is even lower than biogas upgrading.

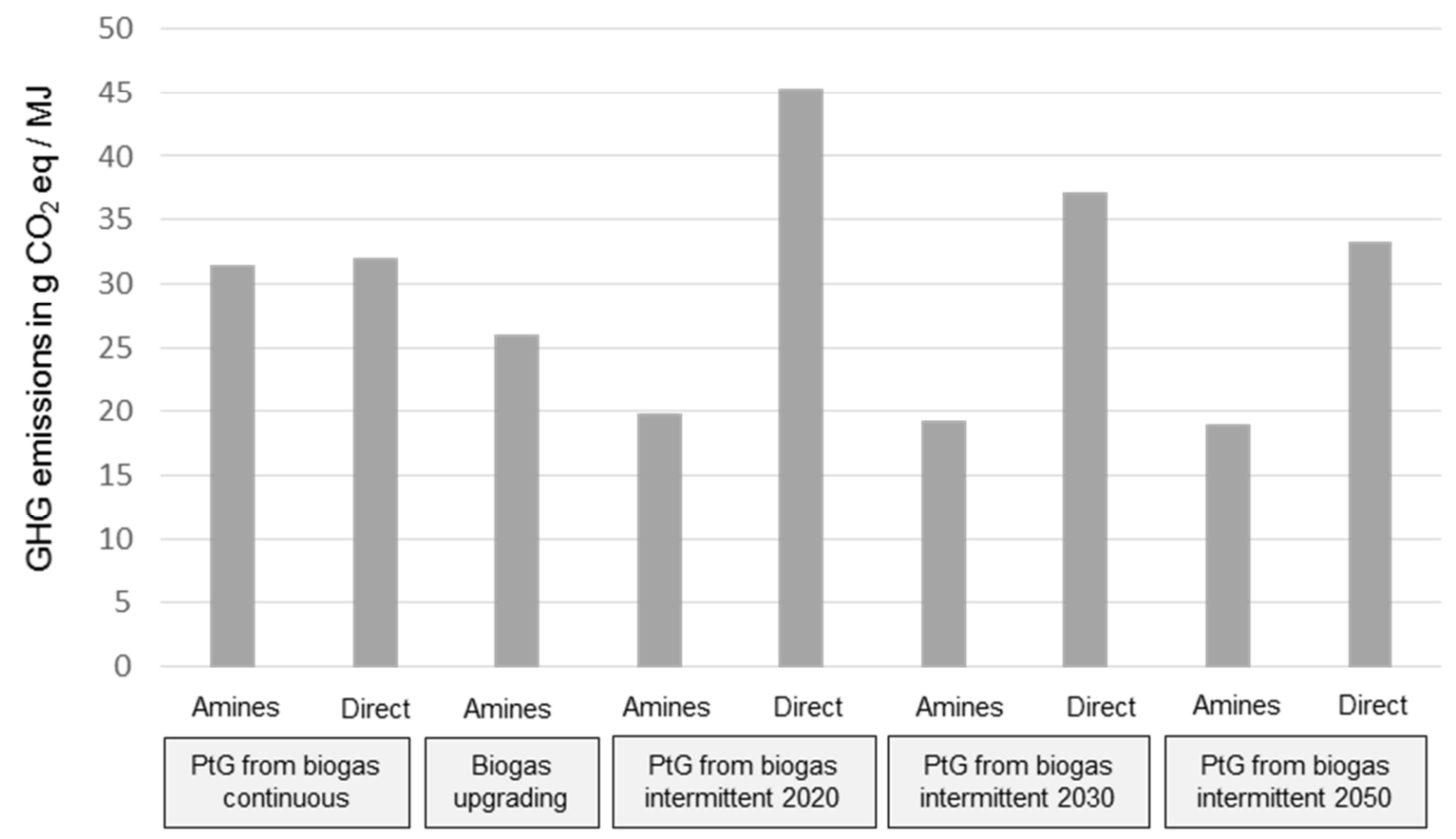

Figure 9: GHG emissions for $1 \mathrm{MJ}$ injected in the gas network depending on the price of electricity and the

Sensitivity analysis

Change in the electricity mix composition operating time

Results of using two different types of electricity are presented on Figure 10 (French electricity mix and European electricity mix). The results indicate that amines PtG technology are more sensitive to the composition of the electricity than biogas upgrading. The change from French electricity mix to European electricity mix induces an increase of $290 \%$ of the GHG emissions of PtG technology, and 
only $70 \%$ of the emissions from biogas upgrading. This is due to the fact that PtG technologies consume much more electricity than upgrading technologies, combined with the different carbon contents of the electricity mix. In fact GHG emissions of $1 \mathrm{MJ}$ of European electricity is $0.156 \mathrm{CO}_{2} \mathrm{eq}$, and only $0.029 \mathrm{CO}_{2}$ eq for French electricity, because French mix is mainly composed of nuclear electricity (78\% according to the Ecoinvent database), with very low GHG emissions $(0.00172$ $\mathrm{CO}_{2}$ eq. $\mathrm{MJ}^{-1}$ ). Consequently, with the use of a European electricity mix (or with another average electricity mix with high GHG emissions, like China or United Kingdom), climate change impact of PtG technology becomes higher than natural gas, with the highest contribution coming from the electricity consumption. Thus electricity with low carbon content is a mandatory prerequisite to achieve a sustainable production of $\mathrm{CH}_{4}$ from $\mathrm{CO}_{2}$.

200

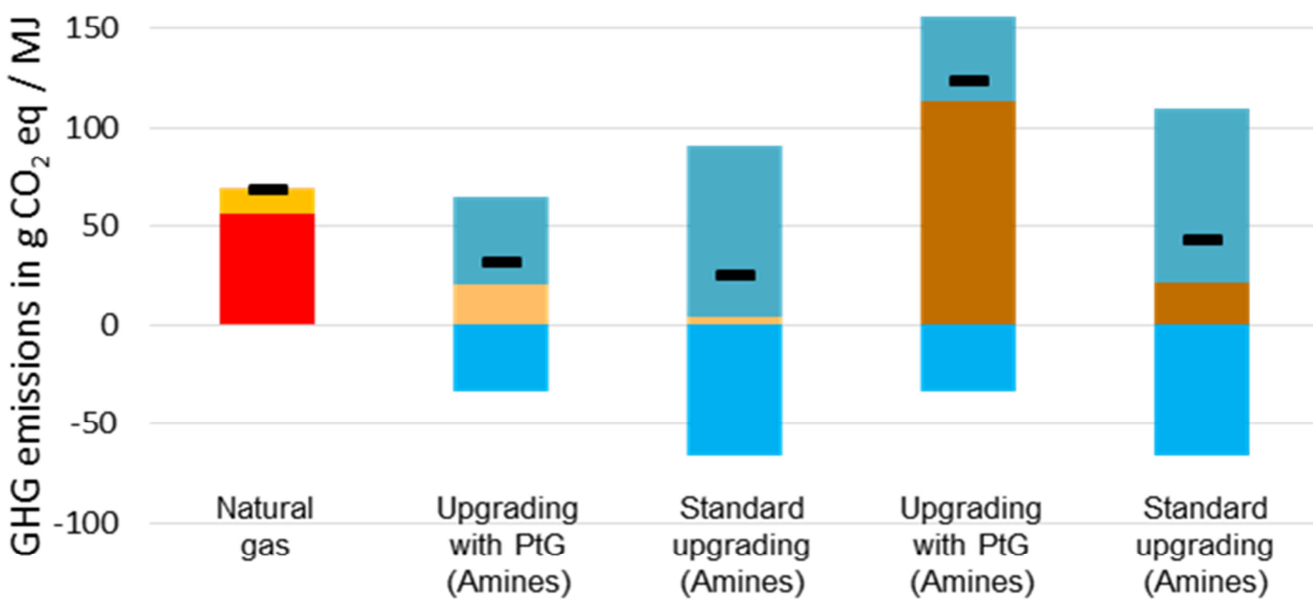

\begin{tabular}{|c|c|c|}
\hline & Electricity, FR & Electricity, EU \\
\hline natural gas, burned & Natural gas, at consumer & Electricity, FR \\
\hline Electricity, EU & = Digestates emissions & Digestates substitution \\
\hline
\end{tabular}

\section{Figure 10: Contribution analysis of GHG emissions for $1 \mathrm{MJ}$ injected in the gas network depending on the electricity mix}

\section{Endpoints impacts}

As pointed out by Reiter and Lindorfer, (2015), other impacts than climate change have never been assessed for biomethane produced from PtG. In this article, endpoint impacts have been assessed with the ReCiPe method with normalization values for Europe and the Hierarchist perspective (Goedkoop et al. 2009). This perspective is based on the most common policy principles with regard to time frame and other issues. The time horizon of the selected impact is in this case 100 years. The three assessed endpoint impacts are:

- Human health, defined as the sum of years of life lost and years of life disabled, and expressed in years. 
- Ecosystem diversity, based on the loss of species during a certain time in a certain area as, and expressed as the potentially disappeared fraction of species (PDF) integrated over area (PDF $x$ year).

- Resources availability, corresponding to the marginal increase in costs due to the extraction of a resource, and expressed in $\$$.

This method is easy to interpret because endpoints are directly associated with an area of protection, unlike midpoints impacts (Reap et al. 2008). On the other hand, it should be noticed that their level of uncertainty is higher than midpoints indicators (Bare et al. 2000). Results are shown on Figure 11, and each impact is standardized with the value of the worst scenario for this impact. As for climate change, impacts of PtG are lower than the ones of natural gas, but higher than biogas upgrading for continuous operation. Contributors of human health and ecosystem impacts are quite the same than for climate change. For resources impact, contributors associated with pollutants emissions are not in the scope of the impact calculation. This leads to negative impact for bioenergy production, as only resource consumption for electricity generation and positive effect of mineral substitution of the mineral fertilizers by the digestates are taken into account.

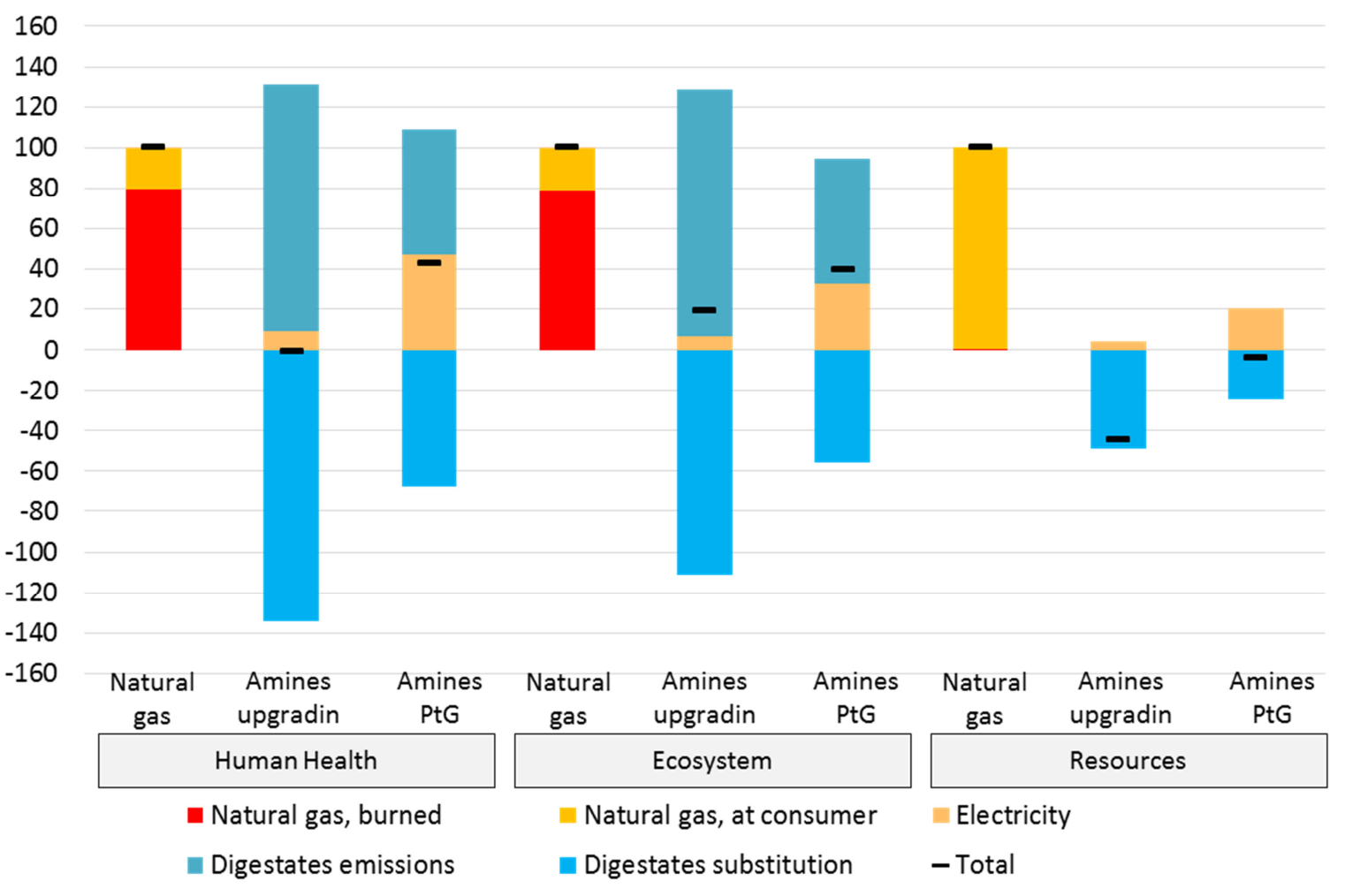




\section{Discussion}

It must be underlined that this is a prospective LCA of a process that does not yet exist. Consequently the systems described in this study can be subjected to important modifications. From a technical point of view, some changes could be proposed to improve the economic and environmental balance of this process. As biogas is used to heat the anaerobic digesters, the $\mathrm{CO}_{2}$ resulting from the combustion of this biogas can also be converted into bioCH $\mathrm{CH}_{4}$ by methanation. The auto-consumption of the biogas ranges from 21\% (membrane upgrading) to 28\% (amines upgrading), so the added amount of bioCH $\mathrm{CH}_{4}$ that could be injected in the gas network is far from being marginal, and could potentially improve the overall performances of the process. About economic assumptions, biogas production costs are based in this paper on French feed-in tariffs and an expected IRR. These values may seem conservative, compared to data from literature (between 0.24 and $0.30 € . \mathrm{m}^{-3}$ of biogas in Patterson et al. (2011)). In the future, a more detailed approach could be investigated to consolidate biogas production costs, for instance by including the biogas production process in the economic assessment. However, as the same biogas production costs have been used for upgrading and PtG technologies, it should be underlined that this inclusion would not change the general conclusion of the economic study. It also has to be noticed that electricity price is strongly correlated with the annual operation hour: average electricity price increases with the load factor (ENEA, 2016). In our study, different electricity prices are proposed for different operation time. This has been done to assess how the analyzed system responds to these two key parameters independently. Further work could therefore integrate price duration curves for different locations and different time horizons in order to map out more clearly potential prospective scenarios. To go deeper into details about the economic feasibility of the combination of anaerobic digestion and PtG technology, the effect of the introduction of an incentive for "green gas" production could be assessed. As underlined by Guandalini et al. (2015), there is a need of specific incentive for PtG technologies in order to push the competitiveness of this energy production system. They propose a "green gas" incentive between 0 and $20 € . \mathrm{MWh}^{-1}$. As this incentive is only related to the $\mathrm{CH}_{4}$ from $\mathrm{CO}_{2}$ conversion by methanation, its amount is function of the proportion of bioCH $\mathrm{CH}_{4}$ from methanation. In our system, $\mathrm{CO}_{2}$ conversion into bioCH $\mathrm{CH}_{4}$ represent approximatively $50 \%$ of the total injected bio $\mathrm{CH}_{4}$ for the amines scrubbing and the membrane upgrading technologies. Applied to the case study described in section 3.1 (continuous operation and an electricity price of $30 € . \mathrm{MWh}^{-1}$ ), an incentive of $20 € . \mathrm{MWh}^{-1}$ leads to a reduction of the production costs of almost $10 \%$. At last learning curves (or experience curves) could be used to quantify the future reduction of investment costs for the different assessed technologies. Progress ratios ( $P R$, defined as the rates of unit cost decline with each doubling of cumulative production) are expected to be around 0.88 (Junginger et al., 2006) for biogas plant and 0.82 for $\mathrm{H}_{2}$ production by 
water electrolysis (Schoots et al., 2008). It is in line with Anandarajah et al. (2013) who report PR around $15-20 \%$ for new technologies. Other authors suggest more globally that investments costs could be divided by 2 in 20 years for thermochemical processes and in 30 years for biochemical processes (due to more important sources of process locks for biological manipulations). From the environmental point of view, conversion of sewage sludge into bio $\mathrm{CH}_{4}$, using methanation to valorize the $\mathrm{CO}_{2}$ of the biogas, can also be seen as a waste treatment process. Many LCAs have been conducted in the past years to assess the environmental impacts of sewage sludge management (Hospido et al. 2010; Sadhukhan 2014; Yoshida et al. 2013). A comparison with the most used technology of sewage sludge valorization in France, i.e the production of electricity and heat by cogeneration, could therefore be an interesting perspective.

\section{Conclusion}

In this study a techno economic and environmental assessment of $\mathrm{bioCH}_{4}$ production via biogas upgrading and PtG technology has been performed. Five different scenarios have been analyzed: two biogas upgrading scenarios (with amines and membrane technologies), and three scenarios with the use of PtG technologies to produce bioCH${ }_{4}$. These scenarios have been compared to a fossil reference scenario of methane production from natural gas. Sensitivity analyzes have been done, both on the economic and environmental assessments. From the economic point of view, PtG technologies are competitive with upgrading ones for an average electricity price equal to $38 € . \mathrm{MWh}^{-}$ ${ }^{1}$ for direct methanation and separation by membranes. The lower competitiveness of amines scrubbing is due to a lower volume of bio $\mathrm{CH}_{4}$ produced, mainly because of the biogas autoconsumption to produce heat for the amines regeneration. For intermittent operation, competitive prices of electricity for methanation can be higher than the upgrading scenarios, depending on the operation time. It should be pointed out that direct methanation cannot be used in intermittent operation, as the produced energy is drastically reduced because of the biogas lost when methanation is not functioning. A reduction of $25 \%$ of the electricity consumption at the electrolysis step causes an important decrease of the production costs, especially for scenarios with high average electricity prices. From an environmental perspective, impacts of PtG are higher than biogas upgrading for continuous operation. Intermittent operation can severely lower the climate change impact for non-direct methanation scenarios, as the consumed electricity is mainly based on renewable sources. The change in the electricity mix composition can also have a strong influence on GHG emissions. This work is a first attempt to assess both the economic and the environmental impacts of PtG technologies, and highlights the main bottlenecks in this production. Here we focus on a simplified process where only $\mathrm{CO}_{2}$ from biogas was converted into $\mathrm{BioCH}_{4}$, but the optimum 
from both environmental and economic points of view may consist in a more complex process where

$\mathrm{CO}_{2}$ from internal biogas combustion should also be turned into bio $\mathrm{CH}_{4}$.

\section{References}

495

496

497

498

499

500

501

502

503

504

505

506

507

508

509

510

511

512

513

514

515

516

517

518

519

520

521

522

523

524

525

526

527

528

529

ADEME, 2014. Etude portant sur l'hydrogène et la méthanation comme procédé de valorisation de l'électricité excédentaire. , pp.1-238.

ADEME, 2011. Qualité agronomique et sanitaire des digestats. , pp.1-250.

ADEME, 2015. Vers un mix électrique 100\% renouvelable en 2050. , pp.1-119.

ADEME, 2012. Vision 2030 - 2050 : L'exercice de prospective de l'ADEME. , pp.1-297.

Alphea, 2015. Fabricants d'électrolyseurs alcalins pour la production d'hydrogène : caractéristiques des produits et informations sur les constructeurs.

Amon, B. et al., 2006. Methane, nitrous oxide and ammonia emissions during storage and after application of dairy cattle slurry and influence of slurry treatment. Agriculture, Ecosystems and Environment, 112(2-3), pp.153-162.

Amor, M. Ben et al., 2014. Implications of integrating electricity supply dynamics into life cycle assessment: A case study of renewable distributed generation. Renewable Energy, 69, pp.410-419. Available at: http://linkinghub.elsevier.com/retrieve/pii/S0960148114002389 [Accessed July 25, 2014].

Anandarajah, G. et al., 2013. Decarbonising road transport with hydrogen and electricity: Long term global

technology learning scenarios. International Journal of Hydrogen Energy, 38(8), pp. 3419-3432.

Bare, J.C. et al., 2000. Midpoints versus endpoints: The sacrifices and benefits. The International Journal of Life Cycle Assessment, 5(6), pp.319-326.

Bauer, F. et al., 2013. Biogas upgrading - Review of commercial technologies. (SGC Rapport; Vol. 270). Svenskt Gastekniskt Center AB, pp. 1-84.

de Boer, H.S. et al., 2014. The application of power-to-gas, pumped hydro storage and compressed air energy storage in an electricity system at different wind power penetration levels. Energy, 72, pp.360-370.

Burkhardt, M. \& Busch, G., 2013. Methanation of hydrogen and carbon dioxide. Applied Energy, 111, pp.74-79. Available at: http://linkinghub.elsevier.com/retrieve/pii/S030626191300384X [Accessed November 6, 2013].

Cetinkaya, E., Dincer, I. \& Naterer, G.F., 2012. Life cycle assessment of various hydrogen production methods. International Journal of Hydrogen Energy, 37(3), pp.2071-2080. Available at: http://linkinghub.elsevier.com/retrieve/pii/S036031991102430X [Accessed June 2, 2014].

DGEC (Direction générale de l'énergie et du climat), 2011. Sommaire Rapport sur l'industrie pétrolière et gazière en 2011. , pp.1-85.

DNV Kema, 2013. System Analysis Power to Gas - Deliverable 1 : Technology Review. , pp.1-70.

Dufour, J. et al., 2012. Life cycle assessment of alternatives for hydrogen production from renewable and fossil sources. International Journal of Hydrogen Energy, 37(2), pp.1173-1183. Available at: http://linkinghub.elsevier.com/retrieve/pii/S0360319911022828 [Accessed June 10, 2014].

Dufour, J. et al., 2009. Life cycle assessment of processes for hydrogen production. Environmental feasibility and reduction of greenhouse gases emissions. International Journal of Hydrogen Energy, 34(3), pp.13701376. Available at: http://linkinghub.elsevier.com/retrieve/pii/S0360319908016078 [Accessed May 28, 2014].

Ekvall, T. \& Weidema, B.P., 2004. System boundaries and input data in consequential life cycle inventory analysis. The International Journal of Life Cycle Assessment, 9(3), pp.161-171. Available at: http://www.springerlink.com/index/10.1007/BF02994190 [Accessed August 30, 2012].

ENEA, 2016. The potential of power of to gas, pp. 1-51.

European Parliament, 2011. Energy Roadmap 2050.

Foley, J. et al., 2010. Comprehensive life cycle inventories of alternative wastewater treatment systems. Water research, 44(5), pp.1654-66. Available at: http://www.ncbi.nlm.nih.gov/pubmed/20022351 [Accessed July 11, 2014].

Frank, E.D. et al., 2012. Methane and nitrous oxide emissions affect the life-cycle analysis of algal biofuels. Environmental Research Letters, 7(1), p.014030. Available at: http://stacks.iop.org/17489326/7/i=1/a=014030?key=crossref.ae62cbb3318881630d5db3d9be522465 [Accessed May 28, 2013].

Frischknecht, R. et al., 2007. Overview and Methodology, , final report ecoinvent v2.0 No. 1, Swiss Centre for Life Cycle Inventories., 
Gahleitner, G., 2013. Hydrogen from renewable electricity: An international review of power-to-gas pilot plants for stationary applications. International Journal of Hydrogen Energy, 38(5), pp.2039-2061. Available at: http://dx.doi.org/10.1016/j.ijhydene.2012.12.010.

Goedkoop, M. et al., 2009. ReCiPe 2008.

Götz, M. et al., 2016. Renewable Power-to-Gas: A technological and economic review. Renewable Energy, 85, pp.1371-1390.

Graves, C. et al., 2011. Sustainable hydrocarbon fuels by recycling $\mathrm{CO} 2$ and $\mathrm{H} 2 \mathrm{O}$ with renewable or nuclear energy. Renewable and Sustainable Energy Reviews, 15(1), pp.1-23. Available at: http://dx.doi.org/10.1016/j.rser.2010.07.014.

Guandalini, G., Campanari, S. \& Romano, M.C., 2015. Power-to-gas plants and gas turbines for improved wind energy dispatchability : Energy and economic assessment. Applied Energy, 147, pp.117-130. Available at: http://dx.doi.org/10.1016/j.apenergy.2015.02.055.

Hadjipaschalis, I., Poullikkas, A. \& Efthimiou, V., 2009. Overview of current and future energy storage technologies for electric power applications. Renewable and Sustainable Energy Reviews, 13(6-7), pp.1513-1522.

Hoekman, S.K. et al., 2010. CO2 recycling by reaction with renewably-generated hydrogen. International Journal of Greenhouse Gas Control, 4(1), pp.44-50. Available at: http://linkinghub.elsevier.com/retrieve/pii/S1750583609001005 [Accessed November 8, 2013].

Hospido, A. et al., 2010. Environmental assessment of anaerobically digested sludge reuse in agriculture: potential impacts of emerging micropollutants. Water research, 44(10), pp.3225-33. Available at: http://www.ncbi.nlm.nih.gov/pubmed/20347114 [Accessed July 13, 2014].

IEA, 2014. Biogas Country Report. , pp.1-50.

IEA, 2009. Biogas upgrading technologies - developments and innovations. , pp.1-20.

IEA, 2015. Technology roadmap - hydrogen and fuel cells. , pp.1-81.

IPCC, 2007. Climate Change: The Physical Science Basis. Contribution of Working Group I to the Fourth Assessment Report of the Intergovernmental Panel on Climate Change. Cambridge University Press, Cambridge, UK and New York, NY, USA. , pp.1 - 1007.

IPCC, 2011. Renewable Energy Sources and Climate Change Mitigation, Special Report of the Intergovernmental Panel on Climate Change. , pp.1-1088.

ISO, 2006. 14044:2006 Environmental management-life cycle assessment-requirements and guidelines. International Standards Organization.

Jentsch, M., Trost, T. \& Sterner, M., 2011. Evaluation of power-to-gas as long-term storage concept regarding electricity and $\mathrm{CO} 2$ sources.

Junginger, M. et al., 2006. Technological learning in bioenergy systems. Energy Policy, 34, pp. 4024-4041.

Kaparaju, P., 2013. Biogas Upgrading Scenarios in Europe - Status \& Prospects. In International Workshop on Promotion of Biogas Upgrading and Bottling in India and EU August 22 - 24, 2013, IIT Delhi.

Leng, Y. et al., 2012. Solid-state water electrolysis with an alkaline membrane. Journal of the American Chemical Society, 134(22), pp.9054-9057.

Makaruk, A., Miltner, M. \& Harasek, M., 2010. Membrane biogas upgrading processes for the production of natural gas substitute. Separation and Purification Technology, 74(1), pp.83-92. Available at: http://dx.doi.org/10.1016/j.seppur.2010.05.010.

Mohseni, F. et al., 2012. Biogas from renewable electricity - Increasing a climate neutral fuel supply. Applied Energy, 90(1), pp.11-16. Available at: http://linkinghub.elsevier.com/retrieve/pii/\$0306261911004697 [Accessed November 6, 2013].

Mori, M. et al., 2014. Life-cycle assessment of a hydrogen-based uninterruptible power supply system using renewable energy. The International Journal of Life Cycle Assessment. Available at: http://link.springer.com/10.1007/s11367-014-0790-6 [Accessed September 1, 2014].

Nistor, S. et al., 2016. Technical and economic analysis of hydrogen refuelling. Applied Energy, 167, pp.211220.

Ocampo, F., Louis, B. \& Roger, A.-C., 2009. Methanation of carbon dioxide over nickel-based Ce0.72Zr0.2802 mixed oxide catalysts prepared by sol-gel method. Applied Catalysis A: General, 369(1-2), pp.90-96.

Parliament, E., 2009. Directive 2009/28/EC of the European Parliament and of the Council of 23 April 2009 on the promotion of the use of energy from renewable sources.

Patterson, T. et al., 2011. An evaluation of the policy and techno-economic factors affecting the potential for biogas upgrading for transport fuel use in the UK. Energy Policy, 39(3), pp.1806-1816. Available at: http://dx.doi.org/10.1016/j.enpol.2011.01.017.

Patyk, A., Bachmann, T.M. \& Brisse, A., 2013. Life cycle assessment of $\mathrm{H} 2$ generation with high temperature 
electrolysis. International Journal of Hydrogen Energy, 38(10), pp.3865-3880. Available at: http://linkinghub.elsevier.com/retrieve/pii/S0360319913001493 [Accessed November 8, 2013].

Raynal, L. et al., 2011. From MEA to demixing solvents and future steps, a roadmap for lowering the cost of post-combustion carbon capture. Chemical Engineering Journal, 171(3), pp.742-752. Available at: http://dx.doi.org/10.1016/j.cej.2011.01.008.

Reap, J. et al., 2008. A survey of unresolved problems in life cycle assessment. The International Journal of Life Cycle Assessment, 13(4), pp.290-300. Available at: http://www.springerlink.com/index/10.1007/s11367008-0008-x [Accessed October 26, 2012].

Reiter, G. \& Lindorfer, J., 2015. Global warming potential of hydrogen and methane production from renewable electricity via power-to-gas technology. The International Journal of Life Cycle Assessment. Available at: http://link.springer.com/10.1007/s11367-015-0848-0 [Accessed January 22, 2015].

Rivarolo, T. et al., 2016. Hydrogen and methane generation from large hydraulic plant: Thermo-economic multi-level time-dependent optimization. Applied Energy, 113, pp.1737-1745.

Ryckebosch, E., Drouillon, M. \& Vervaeren, H., 2011. Techniques for transformation of biogas to biomethane. Biomass and Bioenergy, 35(5), pp.1633-1645. Available at: http://dx.doi.org/10.1016/j.biombioe.2011.02.033.

Sadhukhan, J., 2014. Distributed and micro-generation from biogas and agricultural application of sewage sludge: Comparative environmental performance analysis using life cycle approaches. Applied Energy, 122, pp.196-206. Available at: http://linkinghub.elsevier.com/retrieve/pii/S0306261914000804 [Accessed September 3, 2014].

Schoots, K. et al., 2008. Learning curves for hydrogen production technology: An assessment of observed cost reductions. International Journal of Hydrogen Energy, 33(11), pp. 2630-2645.

Starr, K. et al., 2012. Life cycle assessment of biogas upgrading technologies. Waste management (New York, N.Y.), 32(5), pp.991-9. Available at: http://www.ncbi.nlm.nih.gov/pubmed/22230660 [Accessed July 24, 2012].

Steeneveldt, R., Berger, B. \& Torp, T.A., 2006. Closing the Knowing - Doing Gap. Chemical Engineering Research and Design, 84(9), pp.739-769.

Sterner, M., 2009. Bioenergy and renewable power methane in integrated $100 \%$ renewable energy systems. , pp.1-230.

Turconi, R. et al., 2014. Environmental impacts of future low-carbon electricity systems: Detailed life cycle assessment of a Danish case study. Applied Energy, 132(x), pp.66-73. Available at: http://linkinghub.elsevier.com/retrieve/pii/S0306261914006606 [Accessed July 23, 2014].

Turconi, R., Boldrin, A. \& Astrup, T., 2013. Life cycle assessment (LCA) of electricity generation technologies: Overview, comparability and limitations. Renewable and Sustainable Energy Reviews, 28, pp.555-565. Available at: http://dx.doi.org/10.1016/j.rser.2013.08.013.

TUV, 2012. Biogas to biomethane technology review, pp. 1-15.

Udagawa, J., Aguiar, P. \& Brandon, N.P., 2007. Hydrogen production through steam electrolysis: Model-based steady state performance of a cathode-supported intermediate temperature solid oxide electrolysis cell. Journal of Power Sources, 166(1), pp.127-136.

Varun, Bhat, I.K. \& Prakash, R., 2009. LCA of renewable energy for electricity generation systems-A review. Renewable and Sustainable Energy Reviews, 13(5), pp.1067-1073.

de Vries, B.J.M., van Vuuren, D.P. \& Hoogwijk, M.M., 2007. Renewable energy sources: Their global potential for the first-half of the 21st century at a global level: An integrated approach. Energy Policy, 35(4), pp.2590-2610.

Wang, M. et al., 2014. The intensification technologies to water electrolysis for hydrogen production - A review. Renewable and Sustainable Energy Reviews, 29, pp.573-588. Available at: http://dx.doi.org/10.1016/j.rser.2013.08.090.

Wang, W. et al., 2011. Recent advances in catalytic hydrogenation of carbon dioxide. Chemical Society reviews, 40(7), pp.3703-3727.

Yan, J. 2016. Integrated Energy Systems. Applied Energy, 167, pp.155-157.

Yoshida, H., Christensen, T.H. \& Scheutz, C., 2013. Life cycle assessment of sewage sludge management: A review. Waste management \& research: the journal of the International Solid Wastes and Public Cleansing Association, ISWA, 31(11), Available at: http://www.ncbi.nlm.nih.gov/pubmed/24061046 [Accessed November 14, 2013].

Zeng, K. \& Zhang, D., 2010. Recent progress in alkaline water electrolysis for hydrogen production and applications. Progress in Energy and Combustion Science, 36(3), pp.307-326. Available at: http://dx.doi.org/10.1016/j.pecs.2009.11.002. 

balancing options in the Baltic States' region. Applied Energy, 170(x), pp.278-285. 